\title{
Core and intact polar glycerol dialkyl glycerol tetraethers (GDGTs) in Sand Pond, Warwick, Rhode Island (USA): Insights into the origin of lacustrine GDGTs
}

\author{
Jessica E. Tierney ${ }^{\mathrm{a}, *}$, Stefan Schouten ${ }^{\mathrm{b}, \mathrm{c}}$, Angela Pitcher ${ }^{\mathrm{b}}$, Ellen C. Hopmans ${ }^{\mathrm{b}}$, \\ Jaap S. Sinninghe Damsté ${ }^{\mathrm{b}, \mathrm{c}}$ \\ ${ }^{a}$ Lamont-Doherty Earth Observatory of Columbia University, 61 Route 9W, Palisades, NY 10964, USA \\ ${ }^{\mathrm{b}}$ NIOZ Royal Netherlands Institute for Sea Research, Department of Marine Organic Biogeochemistry, P.O. \\ Box 59, 1790 AB Den Burg, Texel, The Netherlands \\ ${ }^{\mathrm{c}}$ University of Utrecht, Faculty of Geosciences, P.O. Box 80.021, 3508 TA Utrecht, The Netherlands
}

Received 24 May 2011; accepted in revised form 7 October 2011; available online 17 October 2011

\begin{abstract}
Branched and isoprenoidal glycerol dialkyl glycerol tetraethers (GDGTs) are abundant in lake sediments and have potential use for determining past changes in climate and limnology. However, emerging evidence suggests that both classes of GDGTs can be associated with both allochthonous soil organic matter and in situ production, potentially complicating interpretation of these compounds in lacustrine sedimentary environments. Here, we investigate the "dual source" issue surrounding lacustrine GDGTs - with an emphasis on the branched GDGTs - by studying both core and intact polar GDGTs within a pond and its watershed in Warwick, RI. Significant differences in both absolute concentrations of branched GDGTs and the percent of branched GDGTs present as IPLs between the soils and shallow lake sediments suggests in situ production of these compounds within the lake environment. Principal components analysis of GDGT lipid concentrations and environmental parameters in Sand Pond sediments and soils highlights two prominent trends in the data, one related to the absolute concentrations of "type I" branched GDGTs (brGDGT-I, Ib, Ic) and the majority of the isoprenoidal GDGTs, and another related to the concentration of the more methylated "type III" branched GDGTs (brGDGT-III, IIIb, IIIc) and isoprenoidal GDGT-0. The latter trend exhibits a subsurface maximum in the sediment column, potentially indicating in situ production of more highly methylated branched GDGTs and GDGT- 0 within the lacustrine sediment column. Trends in the distributions of branched GDGTs (as reflected by the MBT and CBT indices) imply mixing of two distinct sources of branched GDGTs (soilderived and in situ), or alternatively, two or more different microbial producers. Both possibilities present a challenge to the application of brGDGT-based paleoenvironmental proxies in lakes. This study highlights the importance of determining the sources of GDGTs to the lacustrine environment prior to paleoenvironmental application.
\end{abstract}

(c) 2011 Elsevier Ltd. All rights reserved.

\section{INTRODUCTION}

In the past decade, the study of the distribution of glycerol dialkyl glycerol tetraether (GDGTs) membrane lipids in sedimentary environments has emerged as a powerful new

\footnotetext{
* Corresponding author. Tel.: +1 8453658406.

E-mail address: tierney@1deo.columbia.edu (J.E. Tierney).
}

method to infer paleoenvironmental change in both marine and lacustrine environments. Chief amongst this body of study is the development and refinement of the $\mathrm{TEX}_{86}$ (Tetraether Index of 86 carbons) proxy for reconstruction of surface water temperatures, primarily sea-surface temperature (SST) (Schouten et al., 2002). The TEX ${ }_{86}$ proxy is based upon the observation that isoprenoidal GDGTs (isoGDGTs) membrane lipids produced by mesophilic Group 1 Crenarchaeota (which have recently been re-classified as a new 
phylum called "Thaumarchaeota;" Brochier-Armanet et al., 2008; Spang et al., 2010; Pitcher et al., 2011) adapt their membrane lipid structure to changes in water temperature in enrichment cultures (Wuchter et al., 2004; Schouten et al., 2007a) and that their fossil lipids in surface marine sediments show an empirical relationship to SST (Schouten et al., 2002; Kim et al., 2008, 2010). Thaumarchaeota are also present in some lacustrine environments, such as the Laurentian Great Lakes and the Great Rift Lakes of East Africa (Keough et al., 2003; Llirós et al., 2010), and in the latter, the $\mathrm{TEX}_{86}$ proxy has been used to reconstruct lake surface water temperatures (Powers et al., 2005; Tierney et al., 2008, 2010a). However, in smaller lakes concentrations of crenarchaeol - a diagnostic lipid for Thaumarchaeota (Sinninghe Damsté et al., 2002) are low and the $\mathrm{TEX}_{86}$ index shows a weak relation to lake temperature, implying that Thaumarchaeota may not be very abundant in these environments (Blaga et al., 2009; Powers et al., 2010). This fundamentally limits the application of the $\mathrm{TEX}_{86}$ proxy to large and/or deep lakes (Powers et al., 2010; Tierney et al., 2010b).

In contrast with the isoGDGTs, the non-isoprenoidal branched GDGTs (brGDGTs), are abundant in both small and large lakes (Powers et al., 2005; Tierney et al., 2008, 2010b; Blaga et al., 2009, 2010; Sinninghe Damsté et al., 2009; Tierney and Russell, 2009; Bechtel et al., 2010; Zink et al., 2010; Sun et al., 2011; Pearson et al., 2011). Though they have archaeal traits, brGDGTs are thought - based on the stereoconfiguration of the glycerol backbone - to be bacterial in origin (Weijers et al., 2006) with Acidobacteria as a potential biological source (Weijers et al., 2009; Peterse et al., 2010; Sinninghe Damsté et al., 2011). The relative degree of cyclization and number of methyl branches of brGDGTs (expressed as the methylation index of branched tetraethers/cyclization index of branched tetraethers MBT/CBT - proxy) in both soils and lakes relates empirically to both environmental $\mathrm{pH}$ and temperature (Weijers et al., 2007a; Tierney et al., 2010b; Sun et al., 2011). On this basis, several studies have used brGDGTs to infer past changes in paleoclimate in both marine (e.g. Weijers et al., 2007b; Donders et al., 2009) and lacustrine (Fawcett et al., 2011) sedimentary environments under the assumption that branched GDGTs are predominantly derived from soil organic matter.

A growing body of literature - including preliminary applications of the MBT/CBT proxy, core-top studies and watershed studies - suggests that the assumption that brGDGTs are exclusively soil-derived in lakes is questionable. Tierney and Russell (2009) demonstrated that the MBT/CBT signature of both lake and river sediments within a lacustrine system in Indonesia is distinctly lower than the MBT/CBT signature of the surrounding watershed soils, and on this basis suggested that brGDGTs could be produced in situ within freshwater environments. Simultaneously, in a study of GDGT fluxes in Lake Challa, East Africa Sinninghe Damsté et al., (2009) observed a similar difference between soil and lake MBT/CBT and concluded that, although in Challa most of the brGDGTs appeared to be derived from soil, an in situ source of brGDGTs could not be excluded. Subsequently, preliminary application of the MBT/CBT proxy to a sediment core from a lake in Scotland (using the global soil calibration of Weijers et al., 2007a) demonstrated good agreement between CBT-inferred lake $\mathrm{pH}$ and diatominferred lake $\mathrm{pH}$, but yielded MBT-inferred temperatures that were substantially cooler than average mean annual air temperatures (Tyler et al., 2010). Similarly, core-top transect studies in Africa (Tierney et al., 2010b) and in New Zealand (Zink et al., 2010) demonstrated that lake MBT/CBT consistently yields colder-than-predicted temperatures (ca. $10^{\circ} \mathrm{C}$ colder) when the global soil calibration (Weijers et al., 2007a) is applied. This "cold bias" is related to the typically lower MBT and CBT values - vis-à-vis watershed soils at the same altitude/air temperature - found in lake sediments. While application of lakes-based calibrations partially ameliorates the lacustrine "cold bias," (Tierney et al., 2010b; Pearson et al., 2011), the coefficient of determination and root mean square of error of the global lakes MBT/CBT calibration is 0.62 and $5.2^{\circ} \mathrm{C}$, respectively (Sun et al., 2011), indicating that much of the variance within the distribution of brGDGTs in lakes remains unexplained. Given the distinction between soil and lake brGDGT distributions, relative changes in the proportion of allochthonous vs. in situ brGDGTs delivered to, and preserved in the lacustrine sedimentary environments may contribute to this uncertainty. Similarly, changes in the delivery or preservation of brGDGTs in time - which are not constrained by coretop studies - could severely hinder the application of a brGDGT-based paleoproxy to lacustrine sediment archives.

Here, we aim to better understand the sources of both branched and isoprenoidal GDGTs to lakes - and the paleoclimatic implications of potential multiple sources of these compounds - by studying the concentration and distribution of both core and intact polar GDGTs in sediments from a freshwater lake named Sand Pond in Warwick, Rhode Island, USA. Intact polar lipids (IPLs) are the building blocks of all cell membranes, and include a wide variety of both phospho- and glycolipids. Upon cell lysis, the polar headgroups of most IPLs are thought to be quickly degraded (White et al., 1979; Harvey et al., 1986), thus the presence of IPLs in an environment can be used as an indication of active, living organisms (e.g. Zink and Mangelsdorf, 2004; Biddle et al., 2006; Van Mooy et al., 2006; Lipp et al., 2008; Schubotz et al., 2009; Van Mooy and Fredricks, 2010). Conversely, core lipids (CLs) represent the relatively apolar lipid backbone that remains after cleavage of the polar headgroup, and are the fossilized remnants of the cellular material. With this framework in mind, we analyzed the absolute concentrations of core GDGTs (C-GDGTs) and intact polar GDGTs (IP-GDGTs) in both soils from the lake watershed as well as downcore within the lacustrine sediment column to investigate whether patterns in IP-GDGT distribution belie the origin of GDGTs, and whether there are relationships between such patterns and environmental or sedimentological conditions.

\section{MATERIALS AND METHODS}

\subsection{Study site}

Sand Pond is a small $\left(0.049 \mathrm{~km}^{2}\right.$; RIDEM, 2007), fresh (surface conductivity $=0.3 \mu \mathrm{S} / \mathrm{cm}$ ), meso-eutrophic (average surface total phosphorus, 1995-2004 = 24 $\mu \mathrm{g} / \mathrm{L}$; 


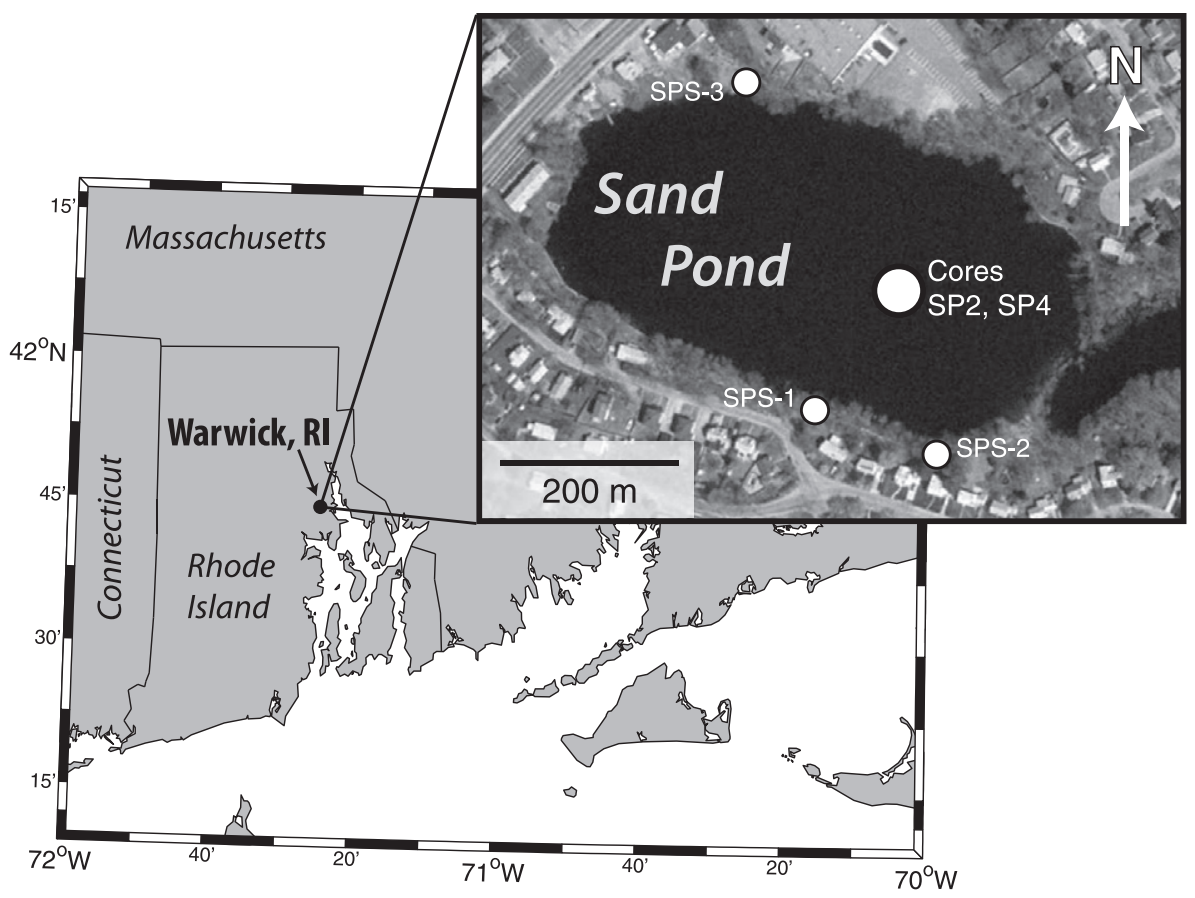

Fig. 1. Sand Pond, our study site, is a small kettle hole pond in Warwick, RI USA. Inset shows the coring site and soil sample locations.

RIDEM, 2007) kettle hole pond located in suburban Warwick, RI, USA $\left(41^{\circ} 44.7^{\prime} \mathrm{N} ; 71^{\circ} 25.5^{\prime} \mathrm{W}\right.$; Fig. 1$)$. Inflow to the lake consists of groundwater, surface water runoff, stormwater drain input, and direct rainfall (RIDEM, 2007). The watershed is small, approximately $0.25 \mathrm{~km}^{2}$, and the lake itself comprises ca. $18 \%$ of the watershed (RIDEM, 2007). Sand Pond was chosen as a study site because it is one of the few naturally occurring kettle hole ponds in the state of Rhode Island, which are steep-sided, deep for their size (Sand Pond is $8 \mathrm{~m}$ deep), and typically contain sediments rich in both terrestrial and aquatic organic matter. Furthermore, Sand Pond's bottom waters are known to be anoxic or suboxic for at least part of the year (RIDEM, 2007), and based on previous inferences that organisms producing brGDGTs thrive in anoxic environments such as peatlands (Weijers et al., 2006), as well as the observation that isoGDGTs are more abundant in lakes with geochemically stratified water columns (Tierney et al., 2010b) we considered this lake an appropriate site to investigate distributions of lacustrine GDGTs.

\subsection{Sedimentary and limnological sampling}

In September 2008, a small gravity core was collected from Sand Pond (SP2; Fig. 1) and extruded on-site at $0.5 \mathrm{~cm}$ resolution up to $5 \mathrm{~cm}$, and then at $1 \mathrm{~cm}$ resolution up to $15 \mathrm{~cm}$. Aliquots of each sample intended for lipid analysis were immediately frozen over dry ice and then stored in a $-70{ }^{\circ} \mathrm{C}$ freezer in the laboratory. In February of 2009, a $164 \mathrm{~cm}$ piston core (SP4) was collected from Sand Pond at the same location as the previous gravity cores in order to recover sediments from deeper within the stratigraphic column (Fig. 1). Upon returning to the laboratory, five deeper sediment slices (at 15, 20, 40, 80 and $120 \mathrm{~cm}$; thickness $1 \mathrm{~cm}$ ) were subsampled from the split core and frozen at $-70^{\circ} \mathrm{C}$ for lipid analyses. In addition, in March of 2009 three soil samples were collected from the Sand Pond watershed (Fig. 1) and were treated similarly as the lake sediment samples.

In both September of 2008 and February of 2009, water column profiles of temperature, $\mathrm{pH}$, conductivity, dissolved oxygen were collected at the coring site with a YSI 6920 V2 sonde.

\subsection{Bulk sedimentary analyses}

Aliquots of sediment samples from SP2 and SP4 were weighed wet, freeze-dried, then weighed again to calculate water content. A subsample of this aliquot was analyzed for total carbon and nitrogen via a Carlo Erba Elemental Analyzer. The remaining sediment was analyzed for elemental concentrations $(\mathrm{S}, \mathrm{Fe}, \mathrm{Ti}$, and $\mathrm{Pb}$ ) via use of an INNOVA-X handheld X-Ray Fluorescence (XRF) detector. Average reproducibility was $1 \%$ of the concentration (ppm) for $\mathrm{Fe}, 4 \%$ for $\mathrm{Ti}, 3 \%$ for $\mathrm{Pb}$ and $10 \%$ for $\mathrm{S}$.

\subsection{Lipid extraction and purification}

Sediment and soil samples stored at $-70{ }^{\circ} \mathrm{C}$ were thawed overnight then wet-extracted $(3 \times)$ using a modified BlighDyer technique (Bligh and Dyer, 1959; Sturt et al., 2004). Ca. $1 \mathrm{~g}$ of wet sediment was placed in a centrifuge tube with a solvent mixture of methanol $(\mathrm{MeOH})$, dichloromethane (DCM) and aqueous phase $(2: 1: 0.8, \mathrm{v} / \mathrm{v} / \mathrm{v})$ with the aqueous phase consisting of sedimentary porewater plus enough phosphate buffer at $\mathrm{pH} 7.4$ to maintain the extraction 
mixture ratio. We elected to wet-extract our samples in this manner because test experiments comparing fresh and freeze-dried aliquots of Sand Pond sediment indicated that freeze-drying reduced GDGT yield for both core and IPL forms by ca. $25 \%$, with losses varying between $5 \%$ and $40 \%$. A previous study of GDGT extraction methods also found that freeze-drying reduced yields (Huguet et al., 2010a). Samples were sonicated for $10 \mathrm{~min}$, centrifuged and then the extract was collected and placed into a separate centrifuge tube. This process was repeated two additional times. DCM and phosphate buffer were added to the resulting extract to achieve a new volume ratio of 1:1:0.9 (v/v/v) and phase separation. The DCM phase containing the extracted lipids and the $\mathrm{MeOH} /$ phosphate buffer phase were separated via centrifuge; separation after centrifugation was clean and no emulsion layers were observed. The DCM phase was collected into a roundbottomed flask. The residue was then rinsed with DCM and centrifuged two additional times, with all DCM phases collected into the flask. The DCM phase containing the total Bligh-Dyer Extract (BDE) was reduced using a rotary evaporator under near vacuum and then completely dried under $\mathrm{N}_{2}$. BDEs were then further separated via silica gel chromatography using a slightly modified version of the separation procedure developed by Oba et al. (2006) and Pitcher et al. (2009) with $4 \mathrm{~mL}$ hexane:ethyl acetate (1:1) (core lipid fraction) and $8 \mathrm{~mL}$ methanol (intact polar lipid fraction) as the respective eluents. Elution scheme experiments revealed that the core branched GDGTs were not completely eluting in a hexane:ethyl acetate mixture of 3:1 (Oba et al., 2006; Pitcher et al., 2009), thus the polarity of the first eluent was increased to hexane:ethyl acetate of $1: 1$ to achieve full separation. After separation, $0.1 \mu \mathrm{g}$ of a $\mathrm{C}_{46}$ synthetic GDGT standard (Huguet et al., 2006) was added to each fraction, respectively. The CL fraction was evaporated under $\mathrm{N}_{2}$ gas to dryness, redissolved in hexane:isopropanol 99:1 (v/v), filtered with a $0.45 \mu \mathrm{m}$ PTFE filter and analyzed via HPLC/MS. The IPL fraction was subjected to acid-catalyzed hydrolysis to cleave polar headgroups by adding $2 \mathrm{~mL}$ of $5 \% \mathrm{HCl}$ in $\mathrm{MeOH}$ and refluxing for $3 \mathrm{~h}$. The solution was cooled to room temperature, adjusted to a $\mathrm{pH}$ of 5 via addition of $1 \mathrm{~N} \mathrm{KOH}$ in $\mathrm{MeOH}$ $(96 \%)$, and then organics-free bidistilled water was added to give a ratio of $\mathrm{H}_{2} \mathrm{O}: \mathrm{MeOH}(1: 1, \mathrm{v} / \mathrm{v})$. The mixture was washed three times with DCM; DCM fractions were subsequently combined and dried over sodium sulfate. The fraction was then processed as described above for the CL fraction.

To compare the efficiency of acid vs. base-catalyzed hydrolysis on cleaving polar GDGT lipids, we analyzed identical $1 \mathrm{mg}$ aliquots of the Bligh-Dyer extract from sample SP2 3-3.25, and in one case processed the aliquot as described above and in the other case, substituted $2 \mathrm{~mL}$ of $1 \mathrm{~N} \mathrm{KOH}$ in $\mathrm{MeOH}(96 \%)$ for the $5 \% \mathrm{HCl}$ in $\mathrm{MeOH}$ to perform base hydrolysis. The aliquot subject to base hydrolysis was refluxed for $1 \mathrm{~h}$, then the solution was cooled to room temperature and adjusted to a $\mathrm{pH}$ of 3 with $5 \% \mathrm{HCl}$ in $\mathrm{MeOH}$. The mixture was then processed as described above.

The sediment residues from the Bligh-Dyer extraction from three representative samples (one from near the sediment surface, one from deeper in the sediment column, and a soil sample) were subject to sequential base and then acid-catalyzed hydrolysis to extract GDGTs bound into the sediment matrix. First, $2 \mathrm{~mL}$ of $1 \mathrm{~N} \mathrm{KOH}$ in $\mathrm{MeOH}(96 \%)$ were added to the residues and the mixture was refluxed for $1 \mathrm{~h}$. The mixture was then cooled to room temperature, and adjusted to a $\mathrm{pH}$ of 3 with $5 \% \mathrm{HCl}$ in $\mathrm{MeOH}$ and extracted as described above only washed six times with DCM. The remaining sediment residue was allowed to dry, then further subject to acid-catalyzed hydrolysis (as described above) to recover remaining bound GDGTs.

\subsection{HPLC/MS analysis}

Prepared fractions were analyzed for both branched and isoprenoidal GDGTs (Fig. 2) via high performance liquid chromatography/positive ion atmospheric pressure chemical ionization mass spectrometry (HPLC/APCI-MS), using selected ion monitoring $(\mathrm{SIM})$ of the $(\mathrm{M}+\mathrm{H})^{+}$ions diagnostic of each GDGT (Fig. 2), on an Agilent/Hewlett Packard 1100 series LC/MSD with an Alltech Prevail Cyano column $(150 \times 2.1 \mathrm{~mm}, 3 \mu \mathrm{m})$, following the methods outlined in Schouten et al. (2007b). GDGTs were eluted isocratically for $5 \mathrm{~min}$. with $90 \% \mathrm{~A}$ and $10 \% \mathrm{~B}$ followed by a linear gradient to $16 \% \mathrm{~B}$ for $45 \mathrm{~min}$, where $\mathrm{A}=$ hexane and $\mathrm{B}=$ hexane:isopropanol 9:1 (v/v). Flow rate was $0.2 \mathrm{~mL} \mathrm{~min}^{-1}$. Injection volume for all samples was $20 \mu \mathrm{L}$. All samples were analyzed in duplicate. MBT and CBT indices were calculated according to the following formulae defined in Weijers et al. (2007a):

$$
\begin{aligned}
\text { MBT } & =\frac{[\text { brGDGT }-\mathrm{I}+\text { brGDGT }-\mathrm{II}+\text { brGDGT-III }]}{\sum \text { brGDGTs }} \\
\mathrm{CBT} & =-\log \frac{[\text { brGDGT-IIb }+ \text { brGDGT }-\mathrm{Ib}]}{[\text { brGDGT-II }+ \text { brGDGT-I }]}
\end{aligned}
$$

Average reproducibility was 0.003 for the MBT index, 0.006 for the CBT index, and 3\% of the given value (in units of $\mu \mathrm{g} / \mathrm{g}$ TOC) for concentrations. Low or undetectable concentrations of some of the isoGDGTs (in particular, isoGDGT-3 and the crenarchaeol isomer) precluded calculation of the $\mathrm{TEX}_{86}$ index. The GDGT-0/crenarchaeol ratio was calculated to express the relative distribution of acyclic vs. cyclic isoGDGTs.

\subsection{Statistical treatment}

All reported correlation coefficients $(r)$ are based on linear ordinary least squares regression, and $p$-values were calculated using one-way analysis of variance (ANOVA). Statistical significance between groups of samples was assessed via use of the nonparametric Wilcoxon-Mann-Whitney test, given that samples within groups were generally not normally distributed. To identify the major trends in the dataset and infer possible environmental controls on GDGT distributions in Sand Pond sediments, we performed principal components analysis (PCA) on the lipid concentrations as well as the metal concentrations, total organic carbon content (TOC), and the atomic carbon:nitrogen ratio $(\mathrm{C} / \mathrm{N})$ using JMP software. PCA was calculated 

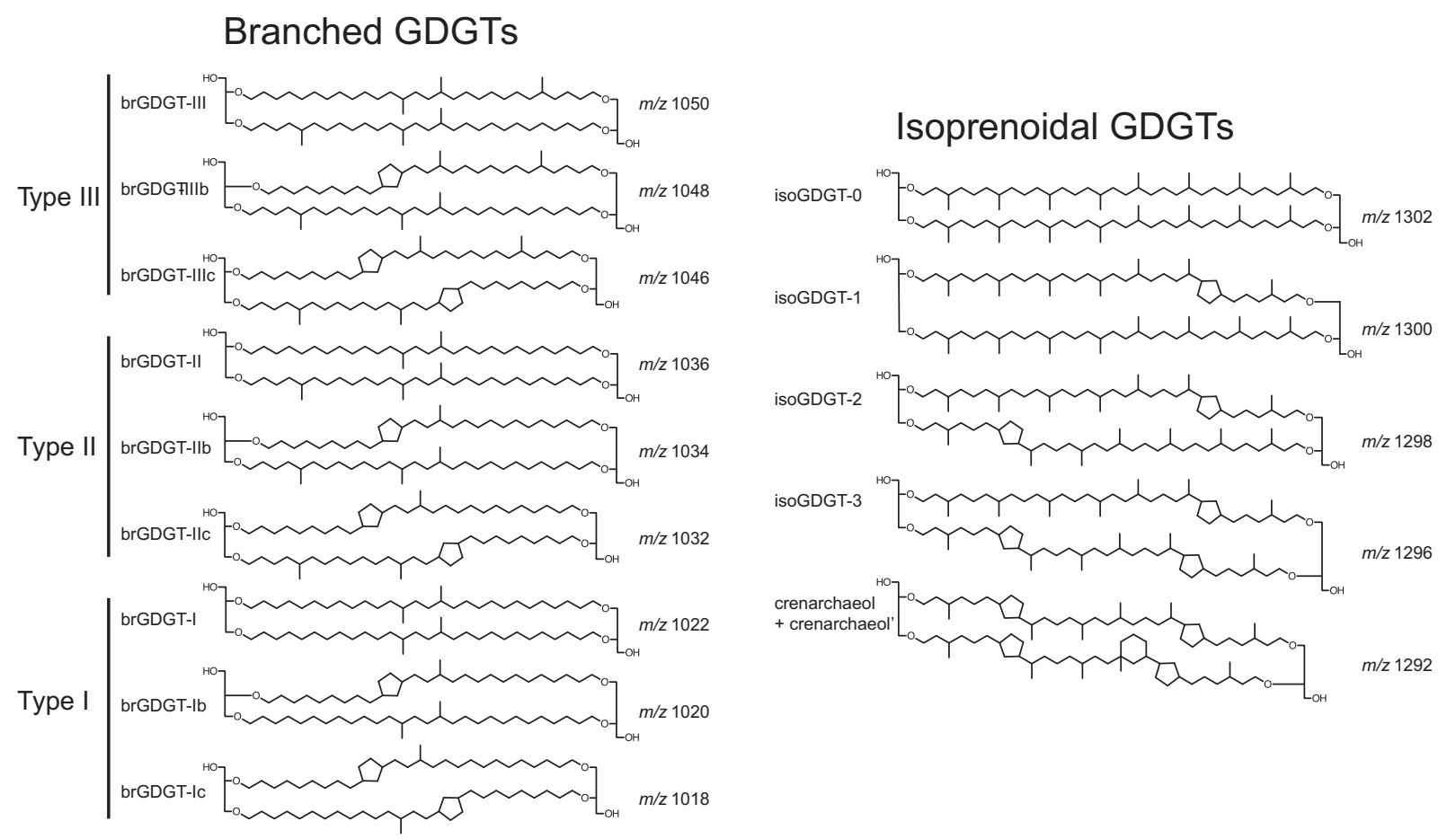

Fig. 2. Structures of the glycerol dialkyl glycerol tetraethers (GDGTs) analyzed in this study, with corresponding $\left[\mathrm{M}+\mathrm{H}^{+}\right]$ions and nomenclature. Crenarchaeol' refers to the isomer of crenarchaeol, whose stereochemistry is not precisely known.

on the correlation matrix and significant components were rotated via use of the varimax algorithm (Kaiser, 1958). Compounds not detected were treated as zeroes in the correlation matrix.

\section{RESULTS}

\subsection{Limnology}

Fig. 3 presents a summary of the temperature, $\mathrm{pH}$, conductivity, and dissolved oxygen (DO) data collected in September (late summer) and February (late winter). DO concentrations are at suboxic levels near the sediment/ water interface in both seasons (Fig. 3). Conductivity is $0.3 \mu \mathrm{S} / \mathrm{cm}$ at the surface but increases slightly towards the bottom of the lake, likely reflecting the accumulation of total dissolved solids as a result of bacterial decomposition of organic matter (Fig. 3). Surface water $\mathrm{pH}$ is $\sim 6.6$ in the summer and $\sim 6.3$ in the winter, and is most acidic at $6 \mathrm{~m}$, below which $\mathrm{pH}$ increases towards the sediment-water interface in both seasons (Fig. 3). Temperature profiles in summer and winter are typical of a mid-latitude, dimictic lake: strong thermal stratification dominates in summer $\left(24{ }^{\circ} \mathrm{C}\right.$ at the surface, $10{ }^{\circ} \mathrm{C}$ at depth; Fig. 3), and in winter, the ice-cover caps an almost isothermal water column (4$5{ }^{\circ} \mathrm{C}$, Fig. 3).

\subsection{Bulk sedimentary data}

Appendix Table 1 lists the bulk geochemical data. Sand Pond sediments are rich in organic carbon (17-24\%) and have intermediary atomic $\mathrm{C} / \mathrm{N}$ ratios (11-16), suggesting that the organic matter in the lake is a roughly equal mixture of soil and algal-derived organic matter (Meyers and Teranes, 2001). Soil $\mathrm{C} / \mathrm{N}$ ratios are substantially higher (20-22) with the exception of soil sample SPS-3 (14.5). SPS-3 was collected from the north side of the lake (Fig. 1), closer to the shore than the other soil samples. It is possible that this area could have been underwater during a period of higher lake level, which could explain why the $\mathrm{C} / \mathrm{N}$ ratio for sample SPS-3 is closer to a value typical of the lake sediments; alternatively, this may just be an expression of the heterogeneity of the watershed soils.

High concentrations of lead between ca. 5 and ca. $15 \mathrm{~cm}$ in the Sand Pond sediment cores (Appendix Table 1, Fig. 4a) are associated with emissions from industrial production as well as the use of leaded gasoline, pervasive pollution sources in Rhode Island from AD 1850-1970 (Nixon, 1995). The return to low concentrations at the top of both cores indicates sedimentation that occurred after the passage of the Clean Air Act Extension (The Muskie Act) in 1970, after which industrial lead emissions were federally regulated and leaded gasoline was phased out. The rise and fall in industrial lead in these sediments can be used to calculate a rough estimate of sedimentation rate in this lake $(1.7 \mathrm{~mm} / \mathrm{yr})$. The lead profiles also allow us to compare stratigraphy between cores SP2 and SP4. The post-1970 interval is more extended in core SP2, typical of a gravity core, but the rise in industrial $\mathrm{Pb}$ appears to occur at similar depths in both cores (Fig. 4a). This indicates that the stratigraphies and sedimentation rates, core tops excluded, are nearly identical between cores, and that no adjustment in 
September 8, 2008
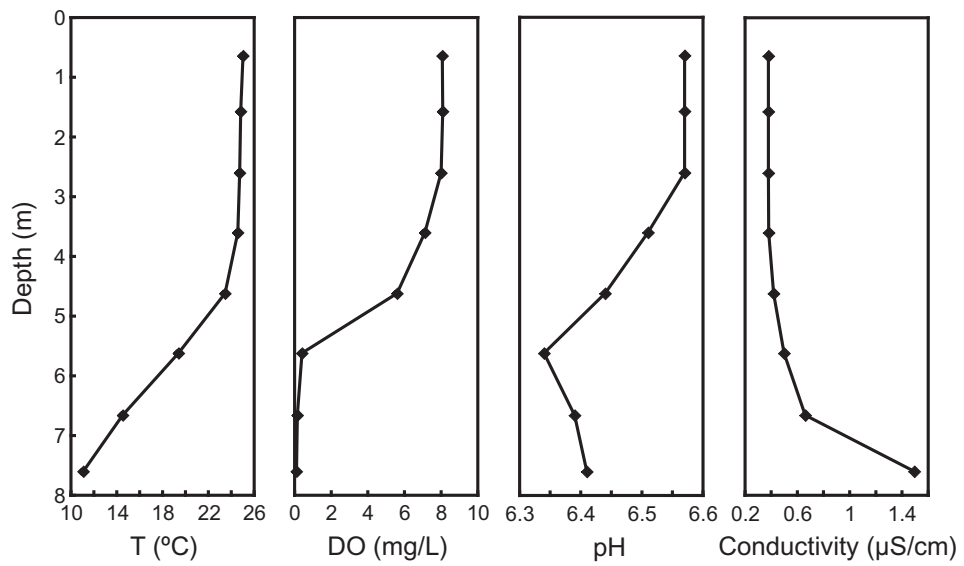

February 18, 2009
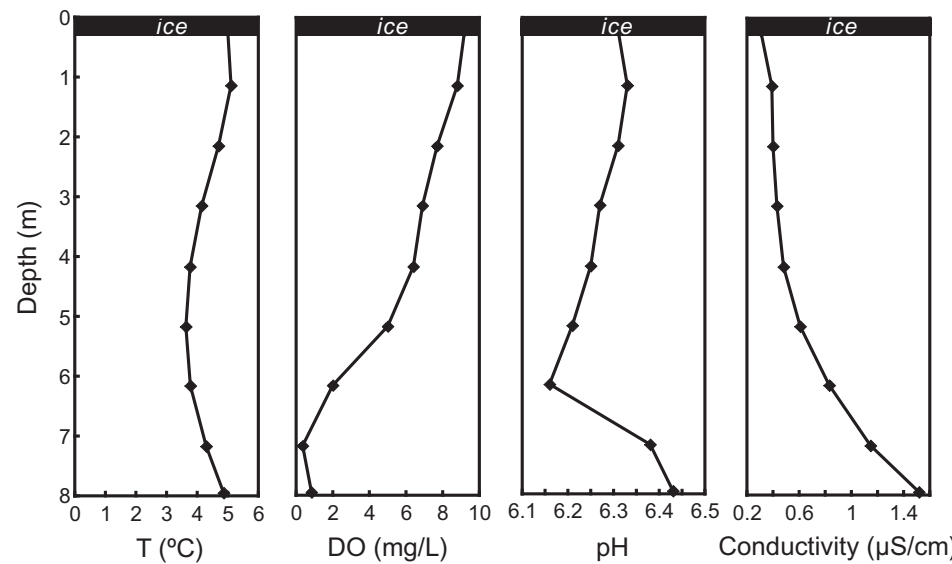

Fig. 3. Temperature, dissolved oxygen (DO), $\mathrm{pH}$ and conductivity water column profiles from Sand Pond in late summer (September) and late winter (February).

depth is needed for comparison of the deeper sediments of SP4 with those of SP2.

The elemental ratio $\mathrm{Fe} / \mathrm{Ti}$, calculated from handheld XRF analyses, spans a range from ca. 7-25 (Appendix Table 1, Fig. 4b). Fe and Ti are both terrigenous elements, but Fe alone is sensitive to the redox state of its depositional environment. Given reducing conditions in an organic-rich, slightly acidic lacustrine environment such as Sand Pond, iron is mobilized and excess $\mathrm{Fe}^{2+}$ may accumulate in sediments as a consequence of redox recycling (Engstrom and Wright, 1984). Normalization to titanium removes variation in iron supply due to enhanced run-off from the watershed, which seems to have occurred in the upper portion of the sediment column (Fig. 4d). Fe/Ti values substantially higher than the watershed soil values (i.e., the oxygenated, background level elemental composition) thus likely represent excess reduced $\mathrm{Fe}$ in the sediments, and by association, a more reducing or anoxic depositional environment. In Sand Pond, Fe/Ti ratios are high in the surface sediments, but approach values similar to those of the soils in the deepest section of SP4 (Fig. 4b). The shift from low to high Fe/Ti occurs between $30-18 \mathrm{~cm}$ (Fig. 4b), and is immediately followed by a visible color transition in the sediments at $18 \mathrm{~cm}$, from a brown facies below to a black facies above. Indeed, after exposure to air for approximately a week, the black facies in core SP4 (split in the laboratory for subsampling) oxidized to a bright red color, confirming the presence of high concentrations $(3-5 \%$; Appendix Table 1) of reduced iron. In contrast, no visible change was observed in the lower, tan facies where Fe/Ti ratios are similar to that of the oxygenated soils (Fig. 4b). In addition, concentrations of XRF-derived sulfur are high within the black facies, but are nearly undetectable in the lower section of the brown facies. Taken together, these data seem to indicate that in the past (brown facies), the depositional environment of Sand Pond was more oxygenated than it is present presently, and that the bottom waters of Sand Pond became increasingly more anoxic over time, promoting the accumulation of reduced iron and sulfur seen in recent times (black facies). Based on the sedimentation rate estimated from the sedimentary $\mathrm{Pb}$ profile (see above), the onset of sub-oxic to anoxic conditions in the lake bottom waters probably occurred towards the end of the 19th century or beginning of the 20th century and is 


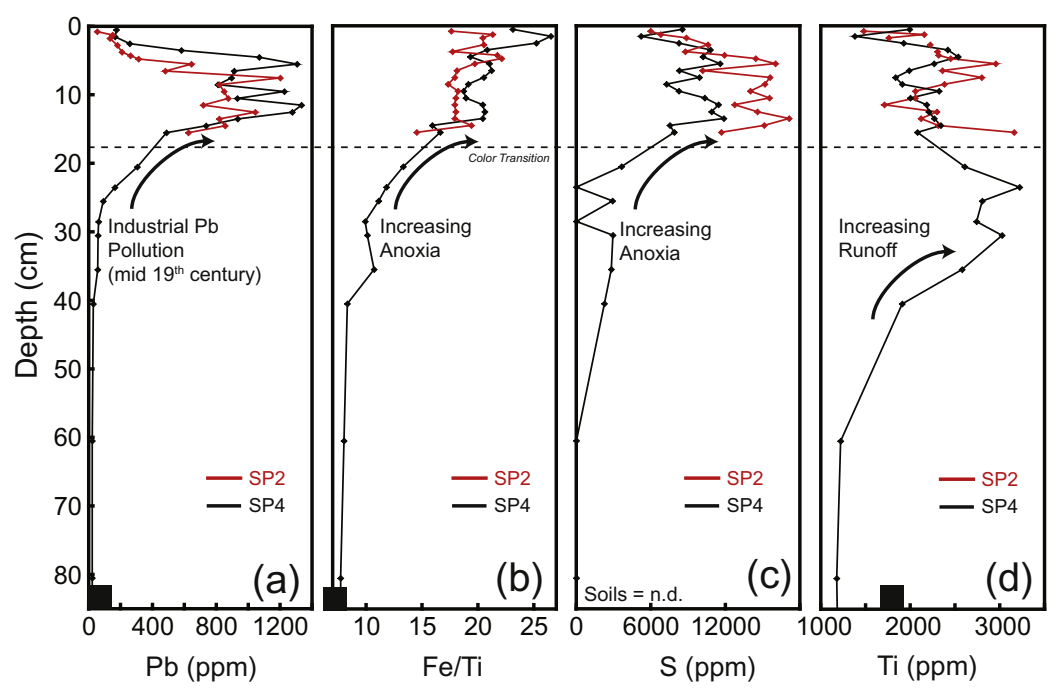

Fig. 4. Lead $(\mathrm{Pb})$ concentrations (a), iron/titanium $(\mathrm{Fe} / \mathrm{Ti})$ ratios $(\mathrm{b})$, sulfur $(\mathrm{S})$ concentrations $(\mathrm{c})$ and titanium $(\mathrm{Ti})$ concentrations $(\mathrm{d})$ in sediment cores SP2 and SP4. High concentrations of $\mathrm{Pb}$ reflect environmental pollution between AD 1850-1970. The industrial $\mathrm{Pb}$ profiles in these sediments allow us to calculate an approximate sedimentation rate $(1.7 \mathrm{~mm} / \mathrm{yr})$. Close agreement between SP2 and SP4 Pb profiles, with the exception of the coretop of SP2, suggests that the stratigraphy between SP2 and SP4 can be assumed to be identical below $15 \mathrm{~cm}$. Increasing $\mathrm{Fe} / \mathrm{Ti}$ ratios (b) towards the top of the sediment column reflect increasing bottom water anoxia in the lake, which is also indicated by the rise in sulfur concentrations (c) and a visual facies color transition (dotted line) from brown, typical of the deep sediment column, to black, a facies that characterizes the upper $18 \mathrm{~cm}$ of the core. Increased deposition of Ti in the upper sediment profile indicates increased lithogenic run-off, likely also a result of settlement and development in the lake watershed. Black squares at the bottom of the plots represent average soil concentrations; n.d. = not detected. (For interpretation of the references to color in this figure legend, the reader is referred to the web version of this article.)

most likely a result of anthropogenic activity - residential development and increased loading of nutrients into this lake increased lake aquatic productivity, resulting in a drawdown of dissolved oxygen (RIDEM, 2007).

\subsection{GDGT lipid analyses}

\subsubsection{Absolute and relative concentrations of GDGT lipids in the core and intact polar lipid fractions}

Appendix Table 2 lists the results from the GDGT analyses of the core lipid (CL) and intact polar lipid (IPL) fractions of the BDEs; the numbering system refers to the GDGT structures in Fig. 2. Downcore trends in GDGT concentrations as well as ratios reflecting their distribution (MBT, CBT and GDGT-0/Crenarchaeol) are summarized in Fig. 5. The dotted line in Fig. 5 indicates the transition described in Section 3.2, above which the sediments were deposited in a low-oxygen lake environment and below which sediments were likely deposited in a more oxygenated lake environment. Both the concentrations of GDGTs and their distribution in the Sand Pond sediment column change notably across this transition. Abundances of type III brGDGTs (brGDGT-III, IIIb and IIIc; Fig. 5a) are relatively high in the surface sediments, reach a local maximum near $4-5 \mathrm{~cm}$ in both the CL and IPL fractions, and then decrease downcore. In contrast, concentrations of type I brGDGTs (brGDGTs I, Ib and Ic) are low in the surface sediments within both CL and IPL fractions and then increase substantially in the lower section of the lacustrine sediment column (Fig. 5c). Type II brGDGTs (brGDGTs II, Ib and IIc) show a trend intermediary between that of type III and type I (Fig. 5b). Most of the isoGDGTs increase in concentration within the deeper sediments (Fig. 5d and e) except for GDGT-0, which decreases in concentration downcore (Fig. 5f). For isoGDGTs 1-3 and GDGT-0, absolute concentrations are higher in the IPL fractions than the CL fractions in both lake sediments and soils. In contrast, concentrations of crenarchaeol and its isomer are lower in the IPL fractions than in the CL fractions in all cases. Generally, the concentrations of isoGDGTs in the IPL fraction (IP-isoGDGTs) are correlated with their corresponding core isoGDGTs (C-isoGDGTs), with the exception of C-crenarchaeol and IP-crenarchaeol concentrations, which are not strongly correlated in the shallow lacustrine sediments $(r=0.27, p=0.36, n=13$; Fig. 5e).

MBT and CBT indices are relatively low in the shallow sediments, but increase and appear to be stable in the deeper sediments (Fig. $5 \mathrm{~g}$ and $\mathrm{h}$ ). The MBT index in the IPL fraction (IP-brGDGTs) trends towards much lower values than the C-brGDGT MBT in the upper $(0-4 \mathrm{~cm})$ sediments due to higher relative abundances of type III GDGTs in the IPL fraction (Fig. 5g), which results in only a moderate correlation between the values of MBT for C-brGDGT and IP-brGDGT in the surface sediment core SP2 $(r=0.65$, $p=0.02, n=13$ ). The CBT index exhibits a local minimum at about $5 \mathrm{~cm}$ in the shallow sediments as a result of locally high concentrations of brGDGTs IIb, IIc and Ib. The GDGT-0/crenarchaeol ratio is high in the surface lacustrine sediments, particularly within in the IPL fraction (ca. 1500), and then drops by nearly an order of magnitude (ca. 200) within the lower sediment column (Fig. 5i). 

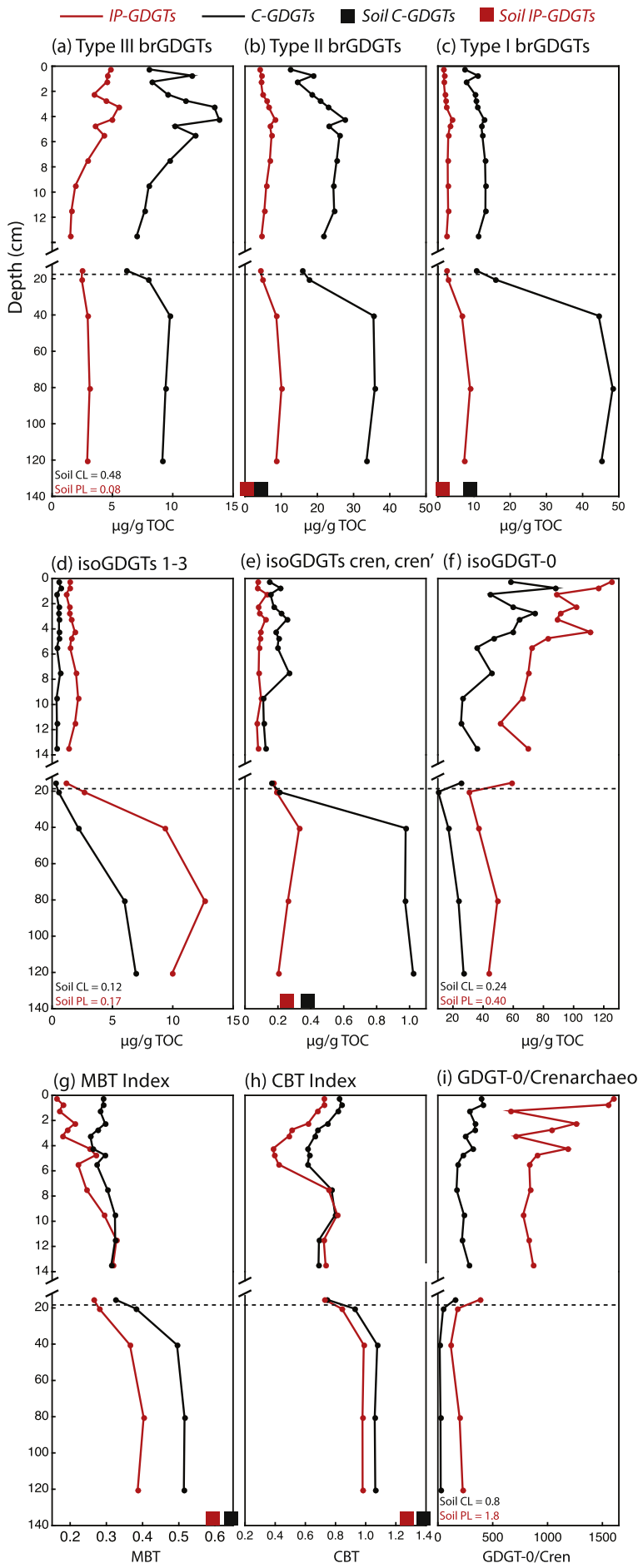

Fig. 5. Downcore profiles of absolute concentrations and relative abundance indices (MBT, CBT, and GDGT-0/crenarchaeol) for intact polar (in red) and core (in black) GDGTs. The dotted line represents the facies transition shown in Fig. 4 and discussed in the main text. Soil mean values are shown for comparison as red (IPGDGTs) and black (C-GDGTs) squares. (For interpretation of the references to color in this figure legend, the reader is referred to the web version of this article.)

Given the major changes that occur in GDGT concentration and distribution across the facies transition, we separate the lake sediments from the shallow horizon $(0$ $15 \mathrm{~cm}$; shallow sediments; SS) from those from the oxic, deep horizon $(>20 \mathrm{~cm}$; deep sediments; DS) in order to compare the GDGT concentrations and distributions of the lake sediments with those in soils from the watershed (Fig. 6). Both shallow and deep lake sediments contain significantly more $(p<0.05)$ type III and type II brGDGTs than the soils (Fig. 6a). The deep lake sediments contain significantly more type I brGDGTs than soils as well, but the concentration of type I brGDGTs in the shallow sediments is not significantly different from that of the soils ( $p=0.12$, Fig. 6a). For the isoprenoidal GDGTs, the concentrations of GDGT- 0 in the lake sediments are ca. two orders of magnitude higher than the concentrations found in soils (note log scale in Fig. 6a). Concentrations of GDGTs $1-3$ are also much higher in the lake sediments, with the highest concentrations found in the deep lake sediments (Fig. 6a), but concentrations of crenarchaeol and its isomer are not significantly different between the lake sediments and the soils (SS-cren vs. soil-cren: $p=0.36$; DS-cren vs. soil-cren: $p=0.23$; Fig. $6 \mathrm{a}$ ).

The fraction of brGDGTs that are present as IPLs (fraction IPL) is significantly higher in the shallow lake sediments than in the soils for all three types of brGDGTs $(p<0.05)$, but not significantly higher in the deep sediments vs. the soils (Fig. 6b). For the isoGDGTs, fraction IPL is not statistically different between surface sediments, deep sediments, and soils within a given group (GDGT-0; GDGTs 1-3; crenarchaeol and its isomer). For the surface and deep lake sediments, fraction IPL for crenarchaeol and its isomer is significantly lower than fraction IPL for GDGTs 0-3 (Fig. 6b). For the soils, there is no significant difference between fraction IPL for any of the isoGDGTs.

The MBT and CBT values of the shallow lake sediments are significantly $(p<0.05)$ lower than soil MBT and CBT in both core and IPL fractions (Fig. 6c) but deep sediment MBT and CBT are not significantly different from soil values. GDGT-0/crenarchaeol ratios vary widely (note log scale in Fig. 6c) and are significantly different between all core and IPL fractions.

\subsubsection{Base and acid hydrolysis of the sediment residues}

We conducted sequential base and acid hydrolysis of the sediment residues after BDE extraction to investigate the concentrations and distributions of GDGTs bound to the sedimentary matrix vis-à-vis the diversity and abundance of GDGTs in the core and IPL fractions. Our results are listed in Appendix Table 2 and visualized in Fig. 7, which displays the relative apportionment of GDGTs between the different lipid fractions. The sequential hydrolysis experiments yielded substantial amounts of both brGDGTs and isoGDGTs, but on a relative basis, the majority of brGDGTs in both the lake sediments and soil are present as core lipids, whereas the majority of isoGDGTs in both lake sediments and soil are present as intact polar lipids or locked into a macromolecular matrix (Fig. 7). In addition, the soils have a much larger proportion of isoGDGTs bound to the matrix than lake sediments (Fig. 7); the amount of compound released by acid hydrolysis of soil in particular is substantial, accounting for ca. $40-90 \%$ of 
(a) Concentrations ( $\mu \mathrm{g} / \mathrm{g}$ TOC)
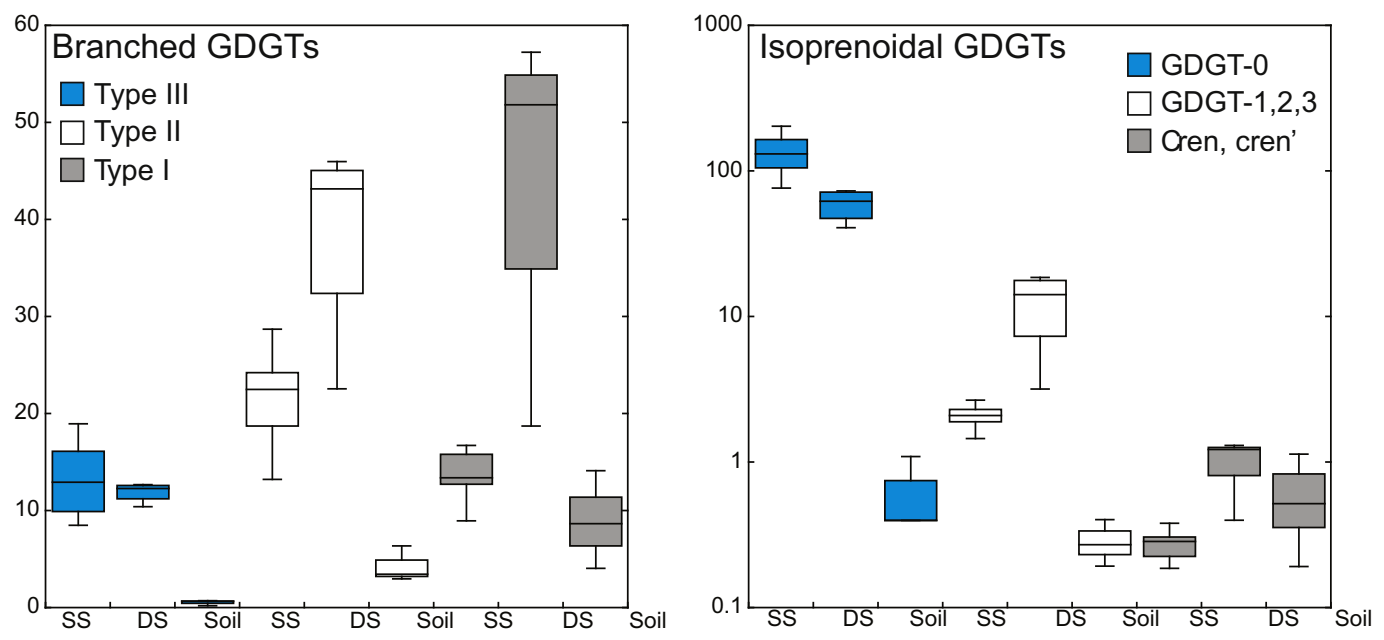

\section{(b) Fraction IPL}
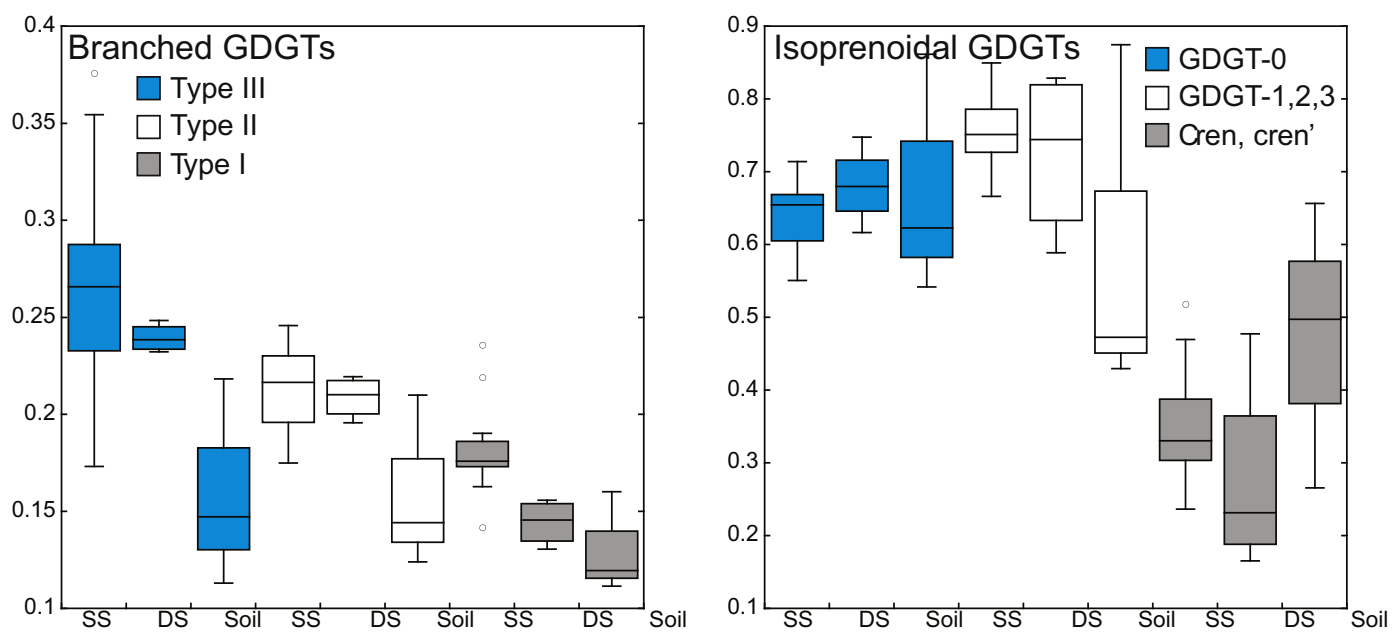

(c) Relative concentration indices

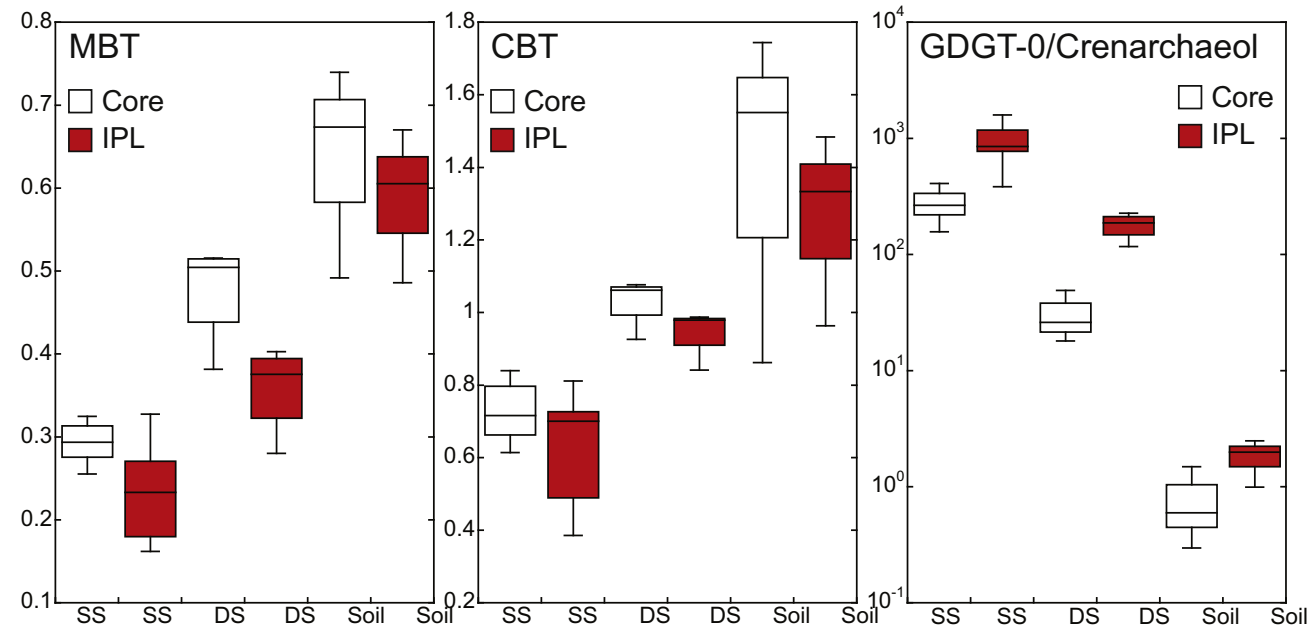

Fig. 6. Box plots revealing differences in (a) GDGT concentrations (normalized to total organic carbon content, in units of $\mu \mathrm{g} / \mathrm{g}$ TOC) (b) the fraction of GDGT lipids present as IPLs and (c) relative GDGT concentrations expressed by the MBT, CBT and GDGT-0/crenarchaeol indices between surface lake sediments $(0-15 \mathrm{~cm}$; SS), deep lake sediments $(15-120 \mathrm{~cm}$; DS) and soils. Note log scales for isoprenoidal GDGT concentrations and the GDGT-0/crenarchaeol ratio. 
the total isoGDGTs (Fig. 7). In contrast, only $9 \%$ of the total brGDGTs in soils were released by acid hydrolysis. Particularly noteworthy is the large amount (almost an order of magnitude more than the amount found in the BDE) of the crenarchaeol isomer that was released after acid hydrolysis of the soil residue. Differences in the brGDGT distributions (represented by the MBT and CBT indices) between the weighted mean of the CL and PL fractions and the hydrolyzed fractions were generally small, with the exception of the CBT values of the shallow sediment sample, which was higher in the base hydrolysis fraction (by 0.14 ) and lower in the acid hydrolyzed fraction (by 0.06), as well as the MBT and CBT value of the acid hydrolyzed deep lake sediment sample, which were 0.12 and 0.3 index units lower than the BDE value, respectively. The GDGT-0/crenarchaeol ratio of the base hydrolysis fraction was comparable to the corresponding core lipid fraction values, and the GDGT-0/crenarchaeol ratio of the acid hydrolysis fraction was comparable to the corresponding IPL fractions with the exception of the surface sediment sample, where the acid hydrolysis GDGT-0/crenarchaeol value (114) is much lower than the IPL fraction value (710).

\subsubsection{Base and acid hydrolysis of the Bligh-Dyer extract}

To assess the efficiency of acid vs. base hydrolysis on release of GDGTs in the IPL fraction, we analyzed identical aliquots of a single BDE and subjected them to each type of hydrolysis, respectively (see Section 2.4) We found that the amount of IP-brGDGTs released by base hydrolysis was moderately lower than the amount released by acid hydrolysis ( $78 \%$ of the amount released by acid hydrolysis). In contrast, for the IP-isoGDGTs the amount released by

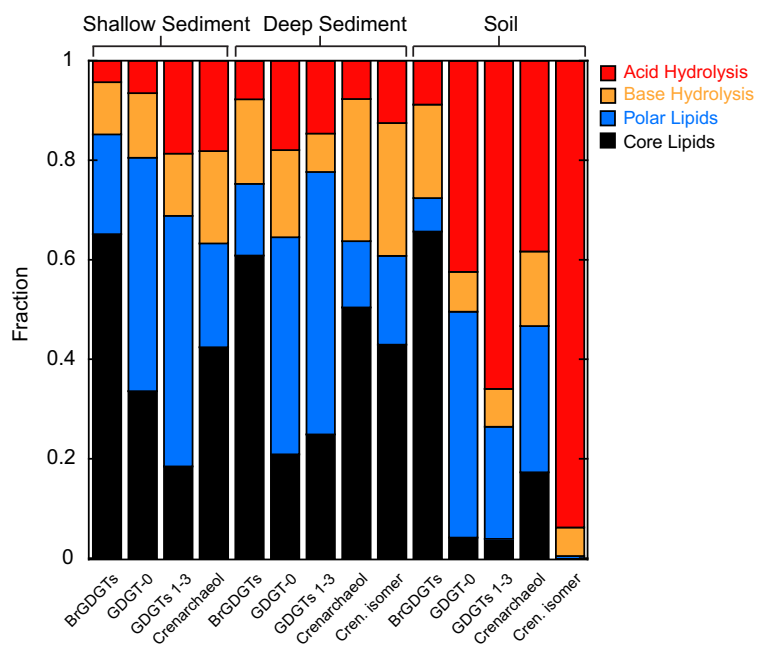

Fig. 7. Cumulative bar plot illustrating the relative distributions of GDGTs between different lipid fractions (core lipids, black; intact polar lipids, blue; base-hydrolysis of the sediment residue, orange; acid hydrolysis of the sediment residue, red) for three representative samples from the shallow sediment horizon, deep sediment horizon, and watershed soils. Distribution of the crenarchaeol isomer in the surface lacustrine sediment is not shown because the isomer was only detectable within the acid hydrolysis fraction. (For interpretation of the references to color in this figure legend, the reader is referred to the web version of this article.) base hydrolysis was substantially lower than acid hydrolysis ( $20 \%$ of the amount released by acid hydrolysis).

\subsection{PCA results}

Principal components analysis of the GDGT lipid and bulk geochemical data from both the sediments and soils identified two prominent trends that explain a cumulative $79 \%$ of the variance. The first principal component (PC1) accounts for $46 \%$ of the variance, and the second component (PC2), 33\%. With the exception of IP-brGDGT-Ib, all of the type I core and IP-brGDGTs load prominently on PC1, along with core and IP-brGDGT-II and core and IP-isoGDGTs 1, 2 and 3 (Fig. 8a). In contrast, the type III core and IP-brGDGTs load primarily onto PC2, along with core and IP GDGT-0, brGDGT-IIb, Fe, and TOC content (Fig. 8a). The $\mathrm{C} / \mathrm{N}$ ratio loads opposite to these variables. Notably, C-crenarchaeol loads primarily along PC1, but its IPL counterpart load differently, with a nearequal expression on both axes. The downcore trends in PC1 and PC2 (Fig. 8b) show that deep sediments dominate
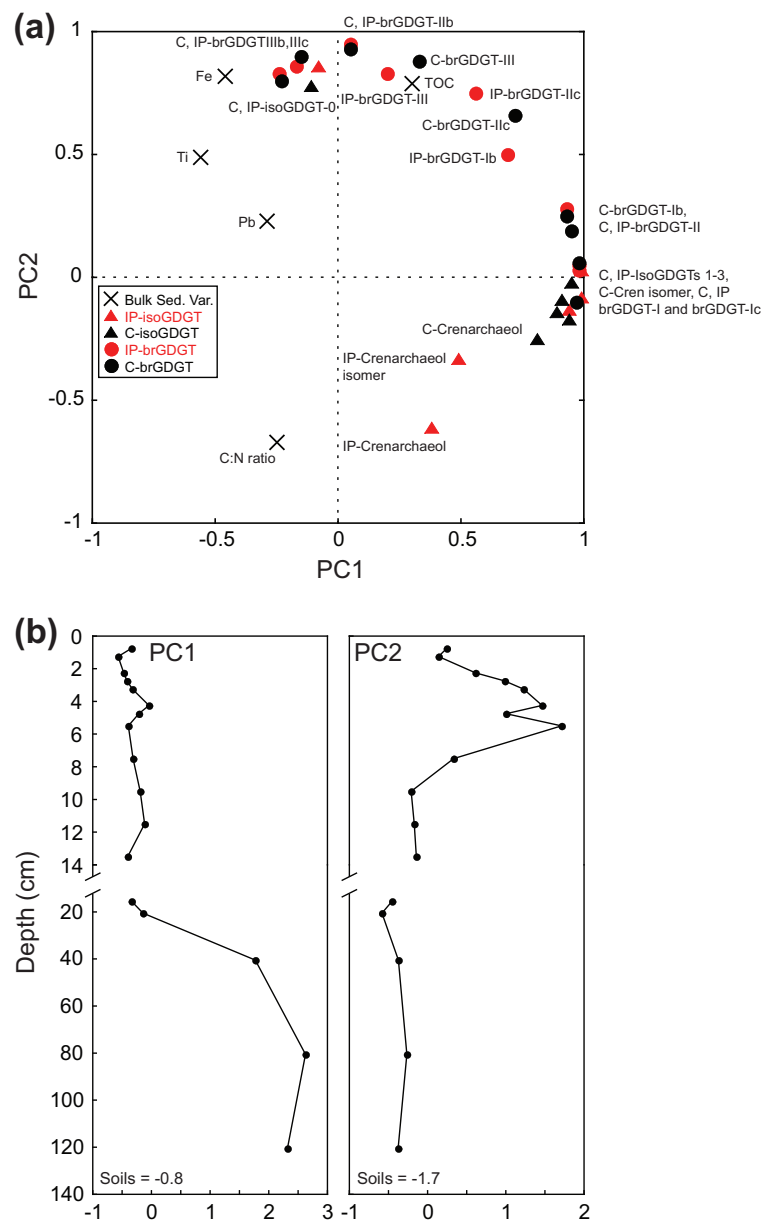

Fig. 8. (a) Principal components analysis (PCA) biplot showing loadings of different GDGTs and bulk sediment variables on the first two components, which comprise $46 \%$ (PC1) and 33\% (PC2) of the total variance in the dataset, respectively. (b) Downcore trends in PC1 and PC2; soil loadings are noted at the bottom. 
the positive loadings of PC1, whereas shallow, subsurface sediments dominate the positive loadings on PC2. Soil samples load negatively on both of the primary PCs.

\section{DISCUSSION}

\subsection{Inferences on the structures of IP-GDGTs in Sand Pond}

As we did not analyze the polar lipids directly in their intact form, we do not know the structure of the polar headgroups that were attached to the GDGTs from Sand Pond prior to hydrolysis. However, considering that base hydrolysis is sufficient for removing phospholipid headgroups, but acid hydrolysis is needed to remove glycolipid headgroups (e.g. Pitcher et al., 2009), results from our base vs. acid hydrolysis comparison (Section 3.3) allow us to indirectly infer the general type of polar headgroups that the IP-GDGTs from the lacustrine sediments may contain. The relatively low efficiency $(20 \%)$ of base hydrolysis with respects to releasing IP-isoGDGTs is expected, as IP-isoGDGT headgroups are known to include hexose moieties (Sturt et al., 2004; Lipp and Hinrichs, 2009; Schouten et al., 2008; Pitcher et al., 2010, 2011) that are not cleaved by base hydrolysis. Thus, the relatively higher efficiency of base hydrolysis in extracting IP-brGDGTs $(78 \%)$ could indicate that the majority, though possibly not all, of the IP-brGDGTs are phospholipids rather than glycolipids. This supports the hypothesis that bacteria and not archaea synthesize branched GDGTs (Weijers et al., 2006), because glycolipids are more typical of archaeal IPLs than bacterial IPLs (Sturt et al., 2004). Recent studies of IP-brGDGTs in peat bogs have detected both hexose (Liu et al., 2010) as well as phospho- and phosphohexose headgroups (Peterse et al., 2011), and the latter, when subjected to base hydrolysis, yielded a substantial amount of core lipids confirming the presence of ester, rather than glycosidic, bonds (Peterse et al., 2011). Thus, we infer from our hydrolysis results that phospholipid brGDGTs may be the predominant - though not exclusive - form of IPL in Sand Pond.

Results from the residue hydrolysis experiment (Appendix Table 2, Fig. 7) also provide indirect information on the nature of lacustrine and soil GDGTs, including insight into the early diagenesis of GDGTs and the relative apportionment of GDGTs between the IPL, CL and sediment-bound fractions. In general, we observe that the majority of the brGDGTs are present in the core lipid fraction in both the soils and lake sediments, whereas the majority of the isoGDGTs are present in the IPL and sediment-bound fractions (Fig. 7). In particular, acid hydrolysis of the soil residue released a relatively large amount of isoGDGTs in comparison with the concentrations found in the other fractions. These results agree with a recent finding that acid hydrolysis treatment releases more isoprenoidal GDGT compounds than branched GDGTs (on a relative basis) in both tropical and temperate podzols (Huguet et al., $2010 \mathrm{~b}$ ). The large release of isoGDGTs from the soil matrix by acid, but not base hydrolysis could reflect the more refractory nature of glycolipid IP-isoGDGTs vs. surmised phospholipid-type IP-brGDGT compounds (Huguet et al., 2010a,b; Schouten et al., 2010, and inferences made above). However, this explanation requires that soil IP-isoGDGTs are incorporated into the macromolecular matrix without first losing their polar headgroups. Though IPLs are typically used as markers for in situ production due to the rapid degradation of their polar headgroups - and that is the rationale in investigating them in this study - glycosidic ether lipids have been observed empirically to degrade far more slowly than phospholipids, even in oxygenated environments (Harvey et al., 1986; Logemann et al., 2011) and theoretical calculations also predict that a far larger proportion of glycosidic ether lipids than phospholipids should be preserved in sedimentary environments (Schouten et al., 2010). Furthermore, isoGDGTs are known to be a significant component of parts of kerogen, with their preservation in macromolecular matrix favored by oxidative cross-linking (Pancost et al., 2008). While studies of IP-isoGDGTs in the marine environment suggest transfer to the core lipid pool on relatively short timescales from a geological perspective (millennial timescales or shorter; Liu et al., 2011), degradation rates of IP-isoGDGTs on the decadal to centennial timescales relevant to our study are not as well constrained. We speculate whether the IPisoGDGTs, with abundant hydroxyl groups, are sufficiently reactive to be rapidly incorporated into the macromolecular matrix within an oxygenated soil environment before lysis of their head groups.

Notably, we found that acid hydrolysis released a much larger quantity, relative to the concentrations in the other lipid fractions, of the crenarchaeol isomer from our soils in Sand Pond in comparison to the other isoGDGTs (Fig. 7); the concentrations of crenarchaeol and the isomer released by acid hydrolysis were nearly equal $(0.39 \mu \mathrm{g} / \mathrm{g}$ TOC vs. $0.33 \mu \mathrm{g} / \mathrm{g}$ TOC, respectively). The high concentrations of the isomer relative to crenarchaeol found in the matrix of the soils suggests a separate origin for this compound, as has been alluded to in marine environments (Shah et al., 2008). One possibility is that the isomer is produced by an unknown type of Group I.1b Thaumarchaeota, whose thermophilic relatives are known produce relatively large amounts of the isomer along with crenarchaeol (Pitcher et al., 2010). The sequestration of the isomer in a fraction of the sediment matrix where acid hydrolysis is needed to release the compound could also suggest a unique functional form for this compound that is easier to lock into the macromolecular matrix, perhaps a form that contains multiple hexose moieties similar to the dihexose isoGDGT IPLs that have been observed in both Thaumarchaeotal culture (Schouten et al., 2008) and in deep-sea sediments (Sturt et al., 2004; Biddle et al., 2006).

\subsection{Sources of GDGTs in lakes}

The fact that both the absolute concentrations of type III and type II brGDGTs in the lake sediments of Sand Pond and the amount of all types of brGDGTs present as IPLs are significantly higher in the shallow lake sediments than in the soils (Fig. 6; Section 3.3.1) is strong circumstantial evidence for in situ production of brGDGTs within lakes; even if IP-brGDGTs survive transport from the watershed soils, it is unlikely that they would preferentially 
accumulate in the lake sediments over the core lipids so as to raise the fraction IPL. The relative distribution of the IPbrGDGTs and accompanying core lipids is also distinct from those of soil brGDGTs and thus suggestive of a different origin. Since the amount of type III brGDGTs present as IPLs is, compared to the soils, the most substantially different (ca. $27 \%$ vs. ca. 14\%; Fig. 6a), this results in a lower MBT index in the surface lake sediments in the IPL fraction (ca. 0.25; Fig. 6c). Higher relative concentrations of brGDGTs-Ib and IIb also result in low CBT indices in the surface lake sediments (ca. 0.6-0.8, Fig. 6c). Our finding that MBT and CBT values in Sand Pond sediments are lower than the watershed soil is in agreement with several previous studies comparing soil and anoxic lake sediments (Sinninghe Damsté et al., 2009; Tierney and Russell, 2009; Bechtel et al., 2010) and the reported reduction in reconstructed mean annual air temperature (MAAT) using brGDGTs in lake sediments (Blaga et al., 2010; Tierney et al., 2010a,b; Zink et al., 2010).

Concentrations of brGDGTs in the deep sediment column are ca. 8-10 times higher than in the watershed soils (Fig. 6a), but the MBT/CBT signature of the deep lake sediments is intermediary between the soil and surface lake values (Fig. 6c). This may indicate a contribution from allochthonous soil-derived brGDGTs in the paleo-lacustrine environment, in particular type I brGDGTs, which have a low fraction IPL in the deep sediments (Fig. 6b) but, of the three types of brGDGTs, have the highest absolute concentrations (Fig. 6a). Given the low absolute concentrations of type I brGDGTs in the soils today, if allochthonous brGDGTs are responsible for the high type I concentrations and intermediary $\mathrm{MBT} / \mathrm{CBT}$ values of the deep lake sediments, it would require that the brGDGT content of paleosols be much higher than at present. While this is plausible - development and land clearance around the lake may have stripped much of the organic matter out of the soils within the past 200 years - we cannot confidently establish whether this is the case.

The concentrations, relative distributions, and IPL representations of the isoGDGTs in Sand Pond suggest primarily autochthonous, but possibly also allochthonous sources for these compounds in Sand Pond. Concentrations of isoGDGT-0, 1, 2 and 3 are 1-2 orders-of-magnitude higher in the lake sediments (Fig. 6a) and most of the compounds present $(60-80 \%)$ are IPLs (Fig. 6b), suggesting either excellent preservation of soil-derived IPL isoGDGTs - some of which might be transported as bound lipids to the sedimentary matrix (see Section 4.1 above) - and/or that these isoGDGTs are produced predominantly in situ. Given the overwhelming dominance of isoGDGT-0 in the lake sediment isoGDGT composition (the GDGT-0/crenarchaeol ratio is ca. 1000 in the IPL fraction of the lake surface sediments; Fig. 6c) we infer that the predominant source of in situ-produced isoGDGTs in Sand Pond is likely methanogenic archaea living in the anoxic deep water or sediment column, which produce primarily isoGDGT-0 and minor amounts of isoGDGTs 1-3 (Koga et al., 1993). This observation is in agreement with a previous study that concluded a high GDGT-0/crenarchaeol ratio in lake environments was diagnostic of a methanogenic source (Blaga et al., 2009). However, downcore concentrations of isoGDGTs 1-3 do not show the same downcore trend as isoGDGT-0 (Fig. 5d and f), suggesting a partially separate origin for these cyclic isoGDGTs. A Thaumarchaeotal source for these seems unlikely because concentrations of crenarchaeol and its isomer (which are diagnostic lipids for Thaumarchaeota; Sinninghe Damsté et al., 2002; Pitcher et al., 2011) are an order-of-magnitude lower than isoGDGTs $1-3$ (Fig. 6a) and only ca. $20-30 \%$ of them are IPLs in the lake sediments as opposed to $60-80 \%$ for isoGDGTs 1-3 (Fig. 6b). Rather, the producer of isoGDGTs 1-3 in this lake environment is more likely another group of archaea - possibly Euryarchaeota.

Concentrations of crenarchaeol are similar between the lake sediments and soils, and the fraction of crenarchaeol present as IPLs is higher in the soils, which promotes the possibility that some of the crenarchaeol in the lake is soil-derived. Indeed, the fact that core and IPL concentrations of crenarchaeol are not correlated in the surface lacustrine sediments (see Section 3.3.1) suggests that there are likely two sources of these compounds - a small in situ source and a relatively larger allochthonous source.

In general, the fraction of isoGDGTs present as IPLs is very high in both the lake sediments and the soils compared with the brGDGTs (Fig. 6b). This could reflect more active production of these compounds in both environments, but also may reflect the more refractory nature of IP-isoGDGTs. As discussed in Section 4.1, the lacustrine brGDGTs may be predominantly phospholipids (and cf. Peterse et al., 2011) and thus may degrade quickly, hence the relatively lower fraction IPL. In contrast, the isoGDGTs may be predominantly composed of glycolipids which are known to be more refractory than phospholipids; thus the higher observed fraction IPL.

The PCA analysis (Fig. 8) provides an additional perspective on the sources of GDGTs in the lake environment in that it clearly identifies two trends in our dataset, implying at least two controls on, or sources of, sedimentary GDGT composition. The first principal component describes the trends in concentration of type I brGDGTs as well as most of the isoGDGTs (apart from GDGT-0) and captures the large increase in GDGT concentration in the deep sediment horizon that is seen in the majority of the branched and isoprenoidal GDGT downcore data (Fig. 5). The soils load negatively on PC1 (Fig. 8b) due to the low absolute concentrations of both branched and isoprenoidal GDGTs, and geochemical indicators of terrestrial input to the lake $(\% \mathrm{Ti}, \mathrm{C} / \mathrm{N}$ ratio) also do not load positively on $\mathrm{PC} 1$. Thus, while $\mathrm{PC} 1$ could be tentatively interpreted to represent variance associated with the delivery of allochthonous GDGT compounds, it does not trend with our geochemical indicators of terrigenous run-off.

PC2 represents variance associated with type III brGDGTs and isoGDGT-0 and exhibits a distinctive subsurface maximum in the sediment column (Fig. 8b). Iron concentrations, which primarily reflect the accumulation of reduced iron during anoxic deposition, also load prominently on PC2. Given the high concentrations of isoGDGT0 in the lake sediments compared with the soils, and the high concentrations and high IPL representation of type 
III brGDGTs, we interpret the variance in PC2 to possibly reflect in situ production of GDGT compounds with a relationship to anoxia. Under this interpretation, the sub-surface peak of PC2 downcore (Fig. 8b) could indicate locally high amounts of in situ production of GDGTs in the lacustrine sediment column at a depth near $5 \mathrm{~cm}$, a depth that may represent the transition to anoxic conditions below the suboxic bottom waters of Sand Pond and/or a suitable redox gradient for the organisms producing these compounds. Alternatively, the sub-surface peak could represent an unknown paleo-event (for example, protracted anoxic conditions due to eutrophication).

Beyond the downcore trends, the PCA biplot (Fig. 8a) indicates that brGDGTs with a larger number of methyl groups load progressively more onto PC2, which promotes several possibilities. One is that the brGDGTs with more methyl groups are more labile, and thus preferentially degraded in allochthonous soil organic matter as well as within oxygenated environments. However, in studies of petroleum degradation, branched alkanes tend to degrade at a slower rate than straight-chain alkanes (e.g. Kennicutt, 1988) which by analogy would suggest that the type III brGDGTs should be more resistant to degradation than the type I brGDGTs rather than the other way around.

Alternatively - and perhaps more likely - an in situ producer of brGDGTs in the lake sediments may produce more of the highly methylated brGDGTs than the soil organisms, and thus the relationship between methylation and oxygen observed in Sand Pond indirectly represents the mixing of two different microbial sources for these compounds. The recent observation that Acidobacteria produce only type I GDGTs (Sinninghe Damsté et al., 2011) supports the possibility that there are likely multiple microbial sources of brGDGTs.

Given that the crenarchaeol isomer was not detected in all samples (Appendix Table 2), its location on the PCA diagram cannot be reliably interpreted, but the behavior of crenarchaeol (present in all samples; Appendix Table 2), is clearly unique in comparison with the other isoGDGTs. The distinct loading of crenarchaeol - in particular, the IPL form - could indicate a different origin of/environmental affect on this compound; namely, given that C-crenarchaeol and IP-crenarchaeol load opposite to $\mathrm{Fe}$ and GDGT-0 (indicators of low-oxygen conditions), their variance could be feasibly attributed to some minor in situ production by lacustrine Thaumarchaeota when the lake is well-oxygenated and by association, less eutrophic. As discussed above, the low concentrations of crenarchaeol and its isomer in the lake sediments suggest that Thaumarchaeota likely do not predominate in Sand Pond. Given that marine ammonium-oxidizing Thaumarchaeota flourish in oligotrophic conditions where ammonium-oxidizing bacteria cannot effectively compete (Martens-Habbena et al., 2009), and that lacustrine Thaumarchaeota appear to prefer deep lakes with a stratified water column with a stable, well-developed chemocline (Tierney et al., 2010b), the size, mixing regime, and/or meso-eutrophic status of Sand Pond might limit the ability of lacustrine Thaumarchaeota to thrive at present.
We note that all three of the distribution indices in this study are strongly correlated with one another (MBT vs. CBT: $r=0.91, p<0.0001, n=48$; MBT vs. $\log$ (GDGT-0/ crenarchaeol): $\quad r=0.93, \quad p<0.0001, n=48 ;$ CBT vs. $\log$ (GDGT-0/crenarchaeol): $r=0.84 p<0.0001, n=48$ ). This may reflect a single, primary control on GDGT distribution in this particular lake environment, which could feasibly be either (1) the mixing of two distinctive sources of GDGTs, e.g. those derived from soil organic matter and those derived from in situ production or (2) a dominant environmental parameter acting on all three indices. As for the latter, oxygen concentration could explain the trend in MBT and CBT by affecting either the production or preservation of these compounds (as discussed above), and also could explain the trend in the GDGT-0/crenarchaeol ratio which is mostly a function of production of GDGT-0 by methanogenic archaea. In some respects, a mixing scenario seems less likely because the soils around Sand Pond presently contain low concentrations of GDGTs in comparison with the lake sediments, hence the negative loading of soils on both principal components in the PCA analysis. We surmise that in all likelihood both of these mechanisms (soil/ in situ mixing; oxygenation) control the abundance and diversity of lacustrine GDGTs.

\subsection{Impact on the paleoenvironmental utility of GDGTs in lakes}

Our core and IPL GDGT lipid data from Sand Pond suggest a sensitivity of the distribution of GDGTs to environmental conditions (e.g. anoxia) and different sources (soil and lacustrine). However, the distribution of brGDGTs in particular (as reflected by MBT and CBT) is known to respond to environmental $\mathrm{pH}$ and temperature (Weijers et al., 2007a), hence the application of brGDGTs towards paleoclimatic reconstruction. Do the brGDGTs in Sand Pond show any relation to these environmental parameters? The range in lake-sediment CBT-inferred $\mathrm{pH}$ values, based on the global soil calibration of Weijers et al. (2007a,b), is 5.9-7.7, a large range given that the actual $\mathrm{pH}$ of Sand Pond lies within a fairly stable range of 6.1-6.6, although these values are technically within the calibration error ( $1 \mathrm{pH}$ unit; 1 sigma). The soils near Sand Pond yield MBT/CBT temperatures $\left(12^{\circ} \mathrm{C}\right)$ identical within calibration error to actual mean annual air temperatures in the Warwick, RI area $\left(11^{\circ} \mathrm{C}\right.$; Global Historical Climatology Network, WMO station 72507.6 [Providence, RI], available at http://www.climexp.knmi.nl), and core brGDGTs from the deepest analyzed section of the lacustrine sediment column predict a temperature of $10{ }^{\circ} \mathrm{C}$, identical to present-day MAAT as well. The surface lake sediments, however, predict temperatures as low as $-5{ }^{\circ} \mathrm{C}$ in the IPL fraction and $0{ }^{\circ} \mathrm{C}$ in the core lipid fraction because the high relative concentrations of primarily type III brGDGTs act to lower the MBT values. This ca. $10^{\circ} \mathrm{C}$ difference between surface sediment MBT/CBT-T and MAAT is the same magnitude as the typical "cold bias" observed in other lake systems (Tierney and Russell, 2009; Bechtel et al., 2010; Blaga et al., 2010; Tierney et al., 2010a,b; Tyler et al., 2010). If we assume that the majority of the brGDGTs in 
the surface sediments are produced in situ, then is possible that the lipids are genuinely reflecting environmental temperature in the sediment column. However, in the case of Sand Pond, basal water temperatures in the lake are $4{ }^{\circ} \mathrm{C}$ in the winter and $11^{\circ} \mathrm{C}$ in the summer (Fig. 3), so the predicted MBT/CBT temperature of the presumed in situ lipids (brGDGTs in the IPL fraction) is still at a minimum 10 degrees lower than sediment-column temperature from the perspective of the Weijers et al. (2007a,b) soil calibration. It seems that the more parsimonious explanation is that any possible paleoenvironmental information encoded within the distribution of the Sand Pond brGDGTs is obscured by the fact that these compounds derive from two sources (soil and in situ) and may also be sensitive, perhaps due to changes in producer communities, to the degree of oxygenation within the environment. The implication of this result is that brGDGT-based paleoproxies may not be suitable for application in small lake environments that either happen to receive a varying amount of soil and aquatic organic matter through time or dramatically change their stratification/oxygenation regime.

We note that while the regional and global core-top calibration studies (Tierney et al., 2010b; Zink et al., 2010; Pearson et al., 2011; Sun et al., 2011) demonstrate that lacustrine brGDGTs respond to environmental temperature across a large spatial temperature gradient, in focusing on surface sediment samples these calibration studies likely capture in situ surface production of the more methylated brGDGTs. Our results from Sand Pond, however, suggest that these in situ brGDGTs can be localized and potentially do not persist downcore. Thus it remains to be seen whether variations in brGDGT composition in one location through time can consistently reflect fluctuations in local temperature, or more often than not are overwhelmed by the changing contribution or preservation of soil and in situ, oxic lake and anoxic lake sources of GDGTs as is the case in Sand Pond. In some situations, these factors may work together. For example, application of the MBT/CBT proxy to a paleolake environment in the southwestern United States (Valles Caldera) demonstrated that the brGDGT-inferred temperatures followed glacial/interglacial variability, with peak interglacial periods $7-8^{\circ} \mathrm{C}$ warmer than glacials (Fawcett et al., 2011) - a promising result for use of brGDGT paleoproxy in lakes. However, lake levels in Valles Caldera were very low during the interglacials, and in some cases the lake may have been desiccated, as it is today (Fawcett et al., 2011). This raises the issue of whether the observed change in brGDGT-temperature in Valles Caldera is due to local temperature change, or alternatively, represents the difference between production or preservation of brGDGTs in a deep-lake, lower-oxygen environment during glacials (leading to lower MBT) vs. production or preservation of brGDGTs in a shallow or sub-aerial, higher-oxygen environment during interglacials (leading to higher MBT). Indeed, our MBT and CBT downcore data from Sand Pond show that a shift from an oxic lake environment to an anoxic lake environment translates into a lowering of MBT/CBT-derived temperature (using the calibration of Weijers et al., $2007 \mathrm{a}$ ) of ca. $9^{\circ} \mathrm{C}$, a value comparable to the soil/lake tem- perature offset observed in previous studies (Tierney and Russell, 2009; Bechtel et al., 2010; Tierney et al., 2010a,b).

A brGDGT-based paleoproxy may be applicable to lakes where the depositional environment has not changed dramatically. For example, Zink et al. (2010) demonstrate that MBT-based temperature inferences in New Zealand lakes agree with independent chironomid-based estimates of temperature change during the last glacial maximum. Similarly, Tyler et al. (2010) demonstrated that the MBT/ CBT paleoproxy captures the trends in acidification and temperature in a lake in Scotland; although the absolute temperature values are too cold and the magnitude of warming is too large, the trends in the data correspond to instrumental records of local temperature as well as diatom-inferred changes in $\mathrm{pH}$. Both studies suggest that brGDGTs in lakes do have value as paleoenvironmental indicators. Furthermore, within the deep sediment column of Sand Pond brGDGT distributions appear to stabilize at certain MBT and CBT values (Fig. $5 \mathrm{~g}$ and $\mathrm{h}$ ) that, at least in the core lipid fraction, predict a reasonable MAAT. This could indicate that the more methylated brGDGTs produced in situ in the shallow lake sediments preferentially do not survive diagenesis, and so in older sedimentary units the "cold bias" may not be as severe as an issue.

It could be argued that the GDGT distributional characteristics in Sand Pond are not representative of most small lakes, as they reflect the transformation of this lake's chemistry and biology by anthropogenic pollution and development. Yet as discussed above, the observed in situ production of the more highly methylated brGDGTs in Sand Pond seems to provide a viable explanation for the "cold bias" seen in the brGDGT distributions in most modern lake environments investigated thus far. Furthermore, in a study of particulate and sedimentary GDGTs in Lake Challa, East Africa - a remote lake not impacted by anthropogenic development - Sinninghe Damsté et al. (2009) show that MBT and CBT values of particulate organic matter (POM) appear to decrease as one moves down the water column from oxic to anoxic waters. The MBT values in particulate matter decrease from ca. 0.3-0.4 in the upper water column to ca. 0.2 in the lower water column (though the sediment MBT value is closer to the surface POM MBT values). In addition, a recent study of two lakes with different trophic status in Switzerland found that the brGDGT distributions in a oligotrophic, well-oxygenated lake predicted regional air temperatures reasonably well, whereas the brGDGTs in the eutrophic lake with anoxic bottom waters - with low sedimentary MBT and CBT indices yielded temperatures that were far too cold (Bechtel et al., 2010). These observations support the inference made here on the basis of the Sand Pond data that in situ production of more methylated brGDGTs in low-oxygen environments leads to lower sedimentary MBT.

\section{CONCLUSIONS}

Our investigation of core and intact polar GDGTs from Sand Pond demonstrates that there are multiple sources of both branched and isoprenoidal GDGTs to small lakes, including soil organic matter, in situ produc- 
tion, and a possible difference between low-oxygen and well-oxygenated lake environments. Of particular note is the evidence for preferential in situ production of the more methylated brGDGTs within the lake sediment column, demonstrated by both the large proportional representation of type III IP-brGDGTs as well as - potentially - the distinct subsurface peak in the absolute downcore concentrations of type III brGDGTs (Fig. 5a). The impact of in situ production of type III brGDGTs is to lower the MBT and CBT indices in surface lake sediments, and this may explain the "cold bias" observed in translation of MBT/CBT values of lacustrine brGDGTs into temperature estimates.

The concentrations and distributions of isoGDGTs in Sand Pond sediments point towards predominantly in situ sources with the exception of crenarchaeol, which may be partially soil-derived. Both the downcore trends and distribution of isoGDGTs in Sand Pond sediments suggest that Thaumarchaeotal presence in the lake is minimal, and that there must be at least two other major producers of isoGDGTs to explain the disparate trends in isoGDGT-0 and isoGDGTs 1-3. Notably, the consistently high representation of IP-isoGDGTs in both lake sediments and soils along with the observation that a large proportion of sedimentary isoGDGTs are locked into the macromolecular matrix of soils suggests that IP-isoGDGTs are relatively refractory.

The apparent preferential production of some brGDGTs in the lacustrine sediment column complicates application of the MBT/CBT paleoproxy in lakes. The Sand Pond sedimentary data show that changes in the relative abundance of allochthonous vs. autochthonous GDGTs and/or a change in the oxygenation of the lake environment through time influences the MBT and CBT indices. Thus, for paleoclimate application of the MBT/CBT proxy it may be best to target lake environments where the watershed and lake characteristics are not thought to change significantly through time. For brGDGT proxies in particular, calibrations-in-time to local instrumental records of temperature or $\mathrm{pH}$ are ideal, as calibrations-in-space based on surface lake sediments may be biased by near-surface production of the highly methylated brGDGTs.

Placing further constraints on the source organisms responsible for synthesizing GDGT lipids in lakes (especially the brGDGTs) would also be prudent prior to paleoclimatic use. Study of the stable or radiogenic carbon isotopic composition of lacustrine GDGT lipids may aid in producer identification by suggesting the metabolic preferences of the producers, as has been done in marine sediments (Shah et al., 2008) and soils (Opperman et al., 2010; Weijers et al., 2010). While lacustrine brGDGTs in particular hold great promise as paleoenvironmental indicators, our study highlights the fact that more groundwork needs to be conducted prior to widespread use of brGDGTbased proxies in lakes.

\section{ACKNOWLEDGEMENTS}

We thank three anonymous reviewers for constructive comments. We thank J. Ossebaar, J. Brandsma, M. Kienhuis and D. Murray for assistance with laboratory analyses and C. Chazen, D. MacDonald and J. Rodysill for assistance in the field. The research leading to these results has received partial funding from the European Research Council under the European Union's Seventh Framework Programme (FP7/20072013)/ERC grant agreement no. 226600. J. Tierney acknowledges the NOAA/UCAR Climate and Global Change Postdoctoral Fellowship for support.

\section{APPENDIX}

See Tables 1 and 2. 
Table 1

Bulk sedimentary data for the cores and soils collected from Sand Pond system. C/N = carbon/nitrogen atomic ratio. n.m. = not measured.

\begin{tabular}{|c|c|c|c|c|c|c|c|c|}
\hline Depth $(\mathrm{cm})$ & Water content $(\%)$ & Nitrogen $(\%)$ & Organic Carbon (\%) & $\mathrm{C} / \mathrm{N}$ (atomic) & $\mathrm{Ti}(\mathrm{ppm})$ & $\mathrm{Fe}(\mathrm{ppm})$ & $\mathrm{S}(\mathrm{ppm})$ & $\mathrm{Pb}(\mathrm{ppm})$ \\
\hline \multicolumn{9}{|l|}{ Core SP2 } \\
\hline 0.25 & 97.4 & 2.2 & 23.9 & 12.5 & n.m. & n.m. & n.m. & n.m. \\
\hline 0.75 & 95.8 & 2.3 & 23.2 & 11.9 & 1480 & 26,000 & 5970 & 52 \\
\hline 1.25 & 94.7 & 2.2 & 23.8 & 12.6 & 2160 & 46,000 & 6790 & 149 \\
\hline 1.75 & 95.1 & 2.2 & 24.0 & 12.9 & 1760 & 35,900 & 8843 & 132 \\
\hline 2.25 & 94.6 & 2.1 & 22.9 & 12.9 & n.m. & n.m. & n.m. & n.m. \\
\hline 2.75 & 94.6 & 1.8 & 20.6 & 13.1 & 2220 & 45600 & 10600 & 179 \\
\hline 3.25 & 94.8 & 2.3 & 22.9 & 11.5 & n.m. & n.m. & n.m & n.m. \\
\hline 3.75 & 95.4 & 2.2 & 22.2 & 11.9 & 2300 & 40,800 & 8755 & 207 \\
\hline 4.25 & 93.7 & 1.9 & 20.8 & 13.0 & 2310 & 50,100 & 11,900 & 261 \\
\hline 4.75 & 93.0 & 1.7 & 20.0 & 13.6 & 2450 & 54,000 & 14,400 & 311 \\
\hline 5.5 & 92.4 & 1.9 & 20.2 & 12.5 & 2950 & 58,200 & 16,000 & 643 \\
\hline 6.5 & 91.1 & 1.6 & 19.1 & 13.8 & 2360 & 42,700 & 10,200 & 479 \\
\hline 7.5 & 89.6 & 1.9 & 18.1 & 11.2 & 2800 & 50,000 & 15,600 & 1200 \\
\hline 8.5 & 89.1 & 1.8 & 19.8 & 13.1 & 2380 & 41,200 & 15,200 & 819 \\
\hline 9.5 & 88.7 & 1.6 & 18.7 & 14.0 & 2060 & 37,400 & 14,000 & 848 \\
\hline 10.5 & 88.3 & 1.5 & 18.7 & 14.8 & 2060 & 37,000 & 15,500 & 873 \\
\hline 11.5 & 88.5 & 2.0 & 18.2 & 10.9 & 1710 & 30,600 & 12,700 & 717 \\
\hline 12.5 & 87.3 & 1.6 & 18.4 & 13.8 & 2300 & 41,300 & 14,600 & 1040 \\
\hline 13.5 & 86.8 & 1.7 & 17.6 & 12.4 & 2120 & 38,000 & 17,100 & 818 \\
\hline 14.5 & 87.4 & 1.6 & 17.8 & 13.0 & 2310 & 44,900 & 15,100 & 855 \\
\hline 15.5 & & & & & 3160 & 45,700 & 11,700 & 624 \\
\hline \multicolumn{9}{|l|}{ Core SP4 } \\
\hline 0.5 & 90.5 & 1.8 & 23.2 & 14.9 & 1990 & 46,000 & 8500 & 173 \\
\hline 1.5 & 92.0 & 1.8 & 22.8 & 15.1 & 1380 & 36,500 & 5190 & 164 \\
\hline 2.5 & 91.5 & 1.6 & 20.0 & 14.7 & 1930 & 48,600 & 8250 & 256 \\
\hline 3.5 & 90.2 & 1.5 & 19.2 & 14.9 & 2420 & 50,400 & 10,800 & 580 \\
\hline 4.5 & 89.4 & 1.4 & 18.3 & 15.6 & 2540 & 49,000 & 10,200 & 1070 \\
\hline 5.5 & 88.5 & 1.4 & 17.8 & 15.2 & 2260 & 47,700 & 11,600 & 1300 \\
\hline 6.5 & 88.3 & 1.4 & 18.0 & 15.4 & 1990 & 42,200 & 8280 & 911 \\
\hline 7.5 & 88.3 & 1.5 & 19.4 & 15.6 & 1830 & 37,600 & 9910 & 894 \\
\hline 8.5 & 88.6 & 1.5 & 19.4 & 15.0 & 1910 & 36,500 & 7260 & 809 \\
\hline 9.5 & 87.6 & 1.4 & 18.8 & 16.3 & 2320 & 43,400 & 8250 & 1230 \\
\hline 10.5 & 87.8 & 1.4 & 18.2 & 15.7 & 2000 & 37,700 & 10,300 & 931 \\
\hline 11.5 & 87.6 & 1.4 & 18.3 & 15.2 & 2180 & 44,600 & 11,500 & 1330 \\
\hline 12.5 & 86.6 & 1.4 & 17.0 & 14.2 & 2210 & 45,300 & 10,900 & 1275 \\
\hline 13.5 & 87.2 & 1.4 & 17.5 & 14.3 & 2270 & 46,200 & 11,900 & 933 \\
\hline 14.5 & 84.6 & 1.2 & 16.6 & 15.6 & 2340 & 37,300 & 7530 & 734 \\
\hline 15.5 & 87.2 & 1.3 & 17.1 & 14.9 & 2080 & 34,600 & 7880 & 487 \\
\hline 20.5 & 86.6 & 1.1 & 17.5 & 19.1 & 2610 & 34,600 & 3640 & 304 \\
\hline 23.5 & n.m. & n.m. & n.m. & n.m. & 3220 & 38,100 & 0 & 163 \\
\hline 25.5 & n.m. & n.m. & n.m. & n.m. & 2800 & 31,100 & 2900 & 90 \\
\hline 28.5 & n.m. & n.m. & n.m. & n.m. & 2740 & 27,100 & 0 & 61 \\
\hline 30.5 & n.m. & n.m. & n.m. & n.m. & 3020 & 30,600 & 2940 & 58 \\
\hline 35.5 & n.m. & n.m. & n.m. & n.m. & 2580 & 27,600 & 2800 & 56 \\
\hline 40.5 & 88.1 & 1.6 & 17.0 & 12.7 & 1910 & 15,900 & 2260 & 28 \\
\hline 60.5 & 88.9 & 2.2 & 24.0 & 13.0 & 1220 & 9770 & 0 & 21 \\
\hline 80.5 & 88.9 & 1.9 & 20.8 & 13.0 & 1180 & 9080 & 0 & 21 \\
\hline 100.5 & 88.4 & 2.0 & 21.9 & 12.9 & 1210 & 9500 & 0 & 24 \\
\hline 120.5 & 87.8 & 1.9 & 21.9 & 13.2 & 1010 & 7550 & 0 & 26 \\
\hline 140.5 & 87.3 & 2.0 & 21.9 & 12.7 & 920 & 6920 & 0 & 26 \\
\hline \multicolumn{9}{|l|}{ Soils } \\
\hline SPS-1 & n.m. & 0.33 & 5.6 & 20.1 & 1890 & 12,900 & n.d. & 47 \\
\hline SPS-2 & n.m. & 0.39 & 7.3 & 22.0 & 1550 & 10,600 & n.d. & 90 \\
\hline SPS-3 & n.m. & 0.72 & 9.0 & 14.5 & 2020 & 13,400 & n.d. & 146 \\
\hline
\end{tabular}


Table 2

Concentrations (as $\mu \mathrm{g} / \mathrm{g}$ TOC) and relative distribution data (MBT, CBT and the GDGT-0/crenarchaeol ratio) for GDGTs in the core and intact polar lipid fractions, and in select sedimentary residues subject to sequential base and then acid hydrolysis after Bligh-Dyer extraction. MBT = Methylation of Branched Tetraethers index (Weijers et al., 2007a), CBT = Cyclization of Branched Tetraethers index (Weijers et al., 2007a). n.d. = not detected.

\begin{tabular}{|c|c|c|c|c|c|c|c|c|c|c|c|c|c|c|c|c|c|c|}
\hline $\begin{array}{l}\text { Depth } \\
(\mathrm{cm})\end{array}$ & $\begin{array}{l}\text { brGDGT- } \\
\text { III }\end{array}$ & $\begin{array}{l}\text { brGDGT- } \\
\text { IIIb }\end{array}$ & $\begin{array}{l}\text { brGDGT- } \\
\text { IIIc }\end{array}$ & $\begin{array}{l}\text { brGDGT- } \\
\text { II }\end{array}$ & $\begin{array}{l}\text { brGDGT- } \\
\text { Iib }\end{array}$ & $\begin{array}{l}\text { brGDGT- } \\
\text { Iic }\end{array}$ & $\begin{array}{l}\text { brGDGT- } \\
\text { I }\end{array}$ & $\begin{array}{l}\text { brGDGT- } \\
\text { Ib }\end{array}$ & $\begin{array}{l}\text { brGDGT- } \\
\text { Ic }\end{array}$ & $\begin{array}{l}\text { isoGDGT- } \\
0\end{array}$ & $\begin{array}{l}\text { isoGDGT- } \\
1\end{array}$ & $\begin{array}{l}\text { isoGDGT- } \\
2\end{array}$ & $\begin{array}{l}\text { isoGDGT- } \\
3\end{array}$ & $\begin{array}{l}\text { Crenar- } \\
\text { chaeol }\end{array}$ & $\begin{array}{l}\text { Crenar- } \\
\text { chaeol } \\
\text { isomer }\end{array}$ & $\mathrm{MBT}^{\mathrm{a}}$ & CBT & $\begin{array}{l}\text { GDGT-0/ } \\
\text { crenarchaeol }\end{array}$ \\
\hline \multicolumn{19}{|c|}{ SP2 - Core lipid fraction } \\
\hline 0.25 & 7.8 & 0.23 & n.d. & 8.6 & 1.4 & 0.079 & 6.4 & 0.87 & 0.18 & 58 & 0.41 & 0.15 & n.d. & 0.15 & n.d. & 0.291 & 0.824 & 395 \\
\hline 0.75 & 11 & 0.42 & n.d. & 13 & 2.1 & 0.11 & 9.6 & 1.2 & 0.20 & 88 & 0.50 & 0.23 & n.d. & 0.21 & n.d. & 0.292 & 0.841 & 411 \\
\hline 1.25 & 7.9 & 0.37 & 0.019 & 9.8 & 1.7 & 0.094 & 6.9 & 0.86 & 0.12 & 45 & 0.26 & 0.11 & n.d. & 0.15 & n.d. & 0.283 & 0.816 & 289 \\
\hline 2.25 & 8.8 & 0.74 & 0.075 & 12 & 2.5 & 0.19 & 8.9 & 1.2 & 0.18 & 60 & 0.38 & 0.19 & n.d. & 0.18 & n.d. & 0.297 & 0.747 & 340 \\
\hline 2.75 & 9.9 & 1.1 & 0.086 & 13 & 3.3 & 0.21 & 9.1 & 1.3 & 0.18 & 74 & 0.39 & 0.14 & n.d. & 0.22 & n.d. & 0.276 & 0.681 & 338 \\
\hline 3.25 & 12 & 1.2 & 0.082 & 14 & 3.8 & 0.23 & 9.4 & 1.4 & 0.18 & 64 & 0.43 & 0.16 & n.d. & 0.26 & n.d. & 0.256 & 0.664 & 250 \\
\hline 4.25 & 13 & 0.91 & 0.080 & 17 & 4.5 & 0.25 & 10 & 2.2 & 0.18 & 60 & 0.47 & 0.11 & n.d. & 0.19 & n.d. & 0.263 & 0.615 & 319 \\
\hline 4.75 & 9.3 & 0.80 & 0.068 & 15 & 3.7 & 0.22 & 9.9 & 2.0 & 0.20 & 47 & 0.46 & 0.12 & n.d. & 0.20 & n.d. & 0.296 & 0.628 & 230 \\
\hline 5.5 & 10 & 1.7 & 0.13 & 16 & 4.7 & 0.28 & 10 & 1.7 & 0.21 & 36 & 0.34 & 0.069 & n.d. & 0.20 & n.d. & 0.273 & 0.615 & 181 \\
\hline 7.5 & 9.2 & 0.52 & n.d. & 17 & 3.0 & 0.15 & 11 & 1.7 & 0.23 & 46 & 0.60 & 0.080 & n.d. & 0.27 & n.d. & 0.303 & 0.774 & 171 \\
\hline 9.5 & 7.8 & 0.26 & n.d. & 17 & 2.6 & 0.15 & 11 & 1.9 & 0.26 & 26 & 0.33 & 0.056 & n.d. & 0.11 & n.d. & 0.324 & 0.798 & 239 \\
\hline 11.5 & 7.4 & 0.30 & n.d. & 16 & 3.2 & 0.18 & 11 & 2.3 & 0.30 & 25 & 0.35 & 0.059 & n.d. & 0.11 & n.d. & 0.325 & 0.691 & 221 \\
\hline 13.5 & 6.7 & 0.30 & n.d. & 14 & 3.0 & 0.14 & 9.1 & 1.8 & 0.20 & 36 & 0.33 & 0.061 & n.d. & 0.13 & n.d. & 0.314 & 0.688 & 284 \\
\hline \multicolumn{19}{|c|}{ SP4 - Core lipid fraction } \\
\hline 15.5 & 6.0 & 0.19 & n.d. & 13 & 2.5 & 0.11 & 8.9 & 1.6 & 0.14 & 25 & 0.25 & 0.042 & n.d. & 0.16 & n.d. & 0.325 & 0.743 & 158 \\
\hline 20.5 & 7.8 & 0.23 & n.d. & 16 & 1.8 & 0.11 & 14 & 1.7 & 0.23 & 10 & 0.39 & 0.13 & 0.029 & 0.21 & n.d. & 0.382 & 0.927 & 49.4 \\
\hline 40.5 & 9.5 & 0.25 & n.d. & 33 & 2.2 & 0.30 & 40 & 3.9 & 0.65 & 17 & 1.4 & 0.60 & 0.18 & 0.94 & 0.034 & 0.495 & 1.08 & 18.1 \\
\hline 80.5 & 9.2 & 0.24 & n.d. & 33 & 2.2 & 0.32 & 43 & 4.5 & 0.73 & 24 & 3.4 & 2.0 & 0.68 & 0.94 & 0.028 & 0.516 & 1.06 & 25.2 \\
\hline 120.5 & 8.9 & 0.23 & n.d. & 31 & 1.9 & 0.29 & 40 & 4.2 & 0.65 & 27 & 3.7 & 2.4 & 0.93 & 0.99 & 0.027 & 0.514 & 1.06 & 27.3 \\
\hline \multicolumn{19}{|c|}{ SP2 - Intact polar lipid fraction } \\
\hline 0.25 & 4.7 & 0.12 & 0.0048 & 2.7 & 0.53 & 0.035 & 1.3 & 0.23 & 0.029 & 125 & 1.0 & 0.44 & 0.030 & 0.078 & n.d. & 0.162 & 0.723 & 1602 \\
\hline 0.75 & 4.4 & 0.15 & 0.011 & 3.0 & 0.64 & 0.044 & 1.6 & 0.23 & 0.023 & 116 & 0.98 & 0.45 & 0.039 & 0.075 & n.d. & 0.180 & 0.725 & 1553 \\
\hline 1.25 & 4.3 & 0.19 & 0.020 & 2.8 & 0.68 & 0.048 & 1.4 & 0.21 & 0.023 & 89 & 0.84 & 0.34 & n.d. & 0.13 & n.d. & 0.170 & 0.680 & 664 \\
\hline 2.25 & 3.1 & 0.34 & 0.035 & 3.0 & 0.87 & 0.070 & 1.7 & 0.26 & 0.030 & 102 & 1.1 & 0.35 & n.d. & 0.081 & n.d. & 0.213 & 0.618 & 1261 \\
\hline 2.75 & 3.9 & 0.49 & 0.044 & 3.4 & 1.29 & 0.10 & 1.8 & 0.33 & 0.029 & 91 & 1.0 & 0.37 & 0.043 & 0.088 & n.d. & 0.192 & 0.510 & 1038 \\
\hline 3.25 & 4.9 & 0.55 & 0.051 & 3.7 & 1.45 & 0.098 & 1.9 & 0.38 & 0.034 & 89 & 1.1 & 0.41 & 0.037 & 0.13 & n.d. & 0.179 & 0.491 & 710 \\
\hline 4.25 & 4.5 & 0.44 & 0.046 & 4.6 & 1.93 & 0.14 & 2.8 & 1.10 & 0.065 & 110 & 1.3 & 0.50 & 0.045 & 0.094 & n.d. & 0.254 & 0.386 & 1174 \\
\hline 4.75 & 3.1 & 0.41 & 0.044 & 3.8 & 1.58 & 0.13 & 2.4 & 0.93 & 0.056 & 83 & 1.2 & 0.35 & n.d. & 0.092 & n.d. & 0.271 & 0.395 & 905 \\
\hline 5.5 & 3.3 & 0.92 & 0.088 & 4.0 & 1.78 & 0.13 & 2.3 & 0.58 & 0.050 & 72 & 1.1 & 0.41 & n.d. & 0.087 & n.d. & 0.222 & 0.423 & 835 \\
\hline 7.5 & 2.7 & 0.21 & 0.0060 & 4.6 & 0.83 & 0.046 & 2.3 & 0.39 & 0.054 & 70 & 1.5 & 0.49 & 0.046 & 0.083 & n.d. & 0.245 & 0.754 & 843 \\
\hline 9.5 & 1.9 & 0.068 & n.d. & 4.1 & 0.57 & 0.041 & 2.3 & 0.41 & 0.066 & 66 & 1.6 & 0.53 & 0.045 & 0.085 & 0.013 & 0.294 & 0.812 & 779 \\
\hline 11.5 & 1.5 & 0.070 & n.d. & 3.6 & 0.65 & 0.042 & 2.3 & 0.47 & 0.078 & 51 & 1.4 & 0.51 & 0.030 & 0.062 & 0.010 & 0.328 & 0.723 & 829 \\
\hline 13.5 & 1.5 & 0.065 & n.d. & 3.1 & 0.56 & 0.038 & 2.0 & 0.38 & 0.046 & 70 & 1.1 & 0.28 & 0.029 & 0.080 & n.d. & 0.319 & 0.735 & 870 \\
\hline \multicolumn{19}{|c|}{ SP4 - Intact polar lipid fraction } \\
\hline 15.5 & 2.4 & 0.055 & n.d. & 3.6 & 0.65 & 0.033 & 2.0 & 0.39 & 0.037 & 59 & 0.81 & 0.28 & 0.073 & 0.15 & 0.021 & 0.265 & 0.728 & 386 \\
\hline 20.5 & 2.4 & 0.087 & n.d. & 4.2 & 0.60 & 0.043 & 2.4 & 0.36 & 0.055 & 31 & 1.8 & 0.75 & 0.11 & 0.17 & 0.020 & 0.281 & 0.843 & 179 \\
\hline 40.5 & 2.9 & 0.075 & n.d. & 7.9 & 0.68 & 0.11 & 5.8 & 0.72 & 0.14 & 37 & 4.8 & 3.8 & 0.79 & 0.31 & 0.018 & 0.365 & 0.989 & 118 \\
\hline 80.5 & 3.0 & 0.086 & n.d. & 9.2 & 0.77 & 0.13 & 7.7 & 1.0 & 0.19 & 50 & 5.9 & 5.0 & 1.7 & 0.25 & 0.012 & 0.403 & 0.980 & 199 \\
\hline 120.5 & 2.8 & 0.073 & n.d. & 7.9 & 0.64 & 0.11 & 6.3 & 0.84 & 0.16 & 44 & 5.2 & 3.9 & 0.88 & 0.19 & 0.011 & 0.387 & 0.981 & 228 \\
\hline
\end{tabular}




\begin{tabular}{|c|c|c|c|c|c|c|c|c|c|c|c|c|c|c|c|c|c|c|}
\hline $\begin{array}{l}\text { Depth } \\
\text { (cm) }\end{array}$ & $\begin{array}{l}\text { brGDGT- } \\
\text { III }\end{array}$ & $\begin{array}{l}\text { brGDGT- } \\
\text { IIIb }\end{array}$ & $\begin{array}{l}\text { brGDGT- } \\
\text { IIIc }\end{array}$ & $\begin{array}{l}\text { brGDGT- } \\
\text { II }\end{array}$ & $\begin{array}{l}\text { brGDGT- } \\
\text { Iib }\end{array}$ & $\begin{array}{l}\text { brGDGT- } \\
\text { Iic }\end{array}$ & $\begin{array}{l}\text { brGDGT- } \\
\text { I }\end{array}$ & $\begin{array}{l}\text { brGDGT- } \\
\text { Ib }\end{array}$ & $\begin{array}{l}\text { brGDGT- } \\
\text { Ic }\end{array}$ & $\begin{array}{l}\text { isoGDGT- } \\
0\end{array}$ & $\begin{array}{l}\text { isoGDGT- } \\
1\end{array}$ & $\begin{array}{l}\text { isoGDGT- } \\
2\end{array}$ & $\begin{array}{l}\text { isoGDGT- } \\
3\end{array}$ & $\begin{array}{l}\text { Crenar- } \\
\text { chaeol }\end{array}$ & $\begin{array}{l}\text { Crenar- } \\
\text { chaeol } \\
\text { isomer }\end{array}$ & $\mathrm{MBT}^{\mathrm{a}}$ & CBT & $\begin{array}{l}\text { GDGT-0/ } \\
\text { crenarchaeo }\end{array}$ \\
\hline \multicolumn{19}{|c|}{ Soils - Core lipid fraction } \\
\hline SPS-1 & 0.59 & n.d. & n.d. & 5.4 & 0.076 & 0.0092 & 12 & 0.24 & 0.038 & 0.14 & 0.057 & 0.045 & 0.0087 & 0.097 & 0.00063 & 0.674 & 1.75 & 1.5 \\
\hline SPS-2 & 0.19 & n.d. & n.d. & 2.3 & 0.038 & 0.012 & 7.0 & 0.22 & 0.053 & 0.057 & 0.014 & 0.016 & 0.0037 & 0.18 & 0.00025 & 0.740 & 1.55 & 0.3 \\
\hline SPS-3 & 0.62 & 0.033 & 0.0073 & 2.7 & 0.35 & 0.026 & 3.1 & 0.45 & 0.046 & 0.51 & 0.10 & 0.081 & 0.030 & 0.84 & 0.0020 & 0.492 & 0.863 & 0.6 \\
\hline \multicolumn{19}{|c|}{ Soils - Intact polar lipid fraction } \\
\hline SPS-1 & 0.10 & n.d. & n.d. & 0.89 & 0.029 & 0.0017 & 1.52 & 0.050 & 0.0064 & 0.24 & 0.045 & 0.030 & 0.0078 & 0.096 & 0.00055 & 0.606 & 1.48 & 2.5 \\
\hline SPS-2 & 0.053 & n.d. & n.d. & 0.60 & 0.028 & 0.0062 & 1.31 & 0.060 & 0.021 & 0.35 & 0.14 & 0.079 & 0.020 & 0.34 & 0.0027 & 0.671 & 1.33 & 1.0 \\
\hline SPS-3 & 0.085 & n.d. & n.d. & 0.39 & 0.039 & 0.0030 & 0.43 & 0.051 & 0.0057 & 0.60 & 0.091 & 0.076 & 0.025 & 0.30 & 0.0016 & 0.486 & 0.964 & 2.0 \\
\hline \multicolumn{19}{|c|}{ Base hydrolysis of residues } \\
\hline $\begin{array}{l}\text { SP2 } \\
3.25\end{array}$ & 1.9 & 0.15 & 0.0090 & 2.7 & 0.50 & 0.023 & 1.4 & 0.20 & 0.017 & 25 & 0.28 & 0.073 & 0.040 & 0.11 & n.d. & 0.235 & 0.764 & 221 \\
\hline $\begin{array}{l}\text { SP4 } \\
80.5\end{array}$ & 3.5 & 0.077 & n.d. & 10 & 0.71 & 0.11 & 10 & 1.2 & 0.200 & 20 & 0.76 & 0.83 & 0.26 & 0.53 & 0.018 & 0.450 & 1.04 & 37.1 \\
\hline SPS-2 & 0.068 & n.d. & n.d. & 0.71 & 0.012 & 0.0049 & 1.9 & 0.062 & 0.013 & 0.11 & 0.032 & 0.024 & 0.0085 & 0.15 & 0.020 & 0.718 & 1.55 & 0.7 \\
\hline \multicolumn{19}{|c|}{ Acid hydrolysis of residues } \\
\hline $\begin{array}{l}\text { SP2 } \\
3.25\end{array}$ & 0.75 & 0.095 & 0.0086 & 0.99 & 0.29 & 0.022 & 0.48 & 0.11 & 0.015 & 12 & 0.34 & 0.222 & 0.023 & 0.11 & 0.020 & 0.220 & 0.564 & 112 \\
\hline $\begin{array}{l}\text { SP4 } \\
80.5\end{array}$ & 1.8 & 0.051 & 0.0036 & 4.7 & 0.66 & 0.15 & 3.3 & 0.91 & 0.25 & 20 & 1.3 & 1.6 & 0.60 & 0.14 & 0.0082 & 0.378 & 0.708 & 143 \\
\hline SPS-2 & 0.033 & n.d. & n.d. & 0.33 & 0.011 & 0.0025 & 0.89 & 0.030 & 0.0062 & 0.56 & 0.20 & 0.29 & 0.077 & 0.39 & 0.33 & 0.710 & 1.48 & 1.4 \\
\hline
\end{tabular}

${ }^{a}$ In the case where one of the GDGTs needed to calculate this index was not detected, a value of 0 was substituted for that GDGT. 


\section{REFERENCES}

Bechtel A., Smittenberg R. H., Bernasconi S. M. and Schubert C. J. (2010) Distribution of branched and isoprenoid tetraether lipids in an oligotropic and a eutrophic Swiss lake: insights into sources and GDGT-based proxies. Org. Geochem. 41, 822-832.

Biddle J. F., Lipp J. S., Lever M. A., Lloyd K. G., Sørensen K. B., Anderson R., Fredricks H. F., Elvert M., Kelly T. J., Schrag D. P., Sogin M. L., Brenchley J. E., Teske A., House C. H. and Hinrichs K. (2006) Heterotrophic archaea dominate sedimentary subsurface ecosystems off Peru. Proc. Natl. Acad. Sci. U.S.A. 103, 3846-3851.

Blaga C. I., Reichart G.-J., Heiri O. and Sinninghe Damsté J. S. (2009) Tetraether membrane lipid distributions in watercolumn particulate matter and sediments: a study of 47 European lakes along a north-south transect. J. Paleolimnol. 41, 523-540.

Blaga C. I., Reichart G.-J., Schouten S., Lotter A. F., Werne J. P., Kosten S., Mazzeo N., Lacerot G. and Sinninghe Damsté J. S. (2010) Branched glycerol dialkyl glycerol tetraethers in lake sediments: can they be used as temperature and $\mathrm{pH}$ proxies? Org. Geochem. 41, 1225-1234.

Bligh E. G. and Dyer W. J. (1959) A rapid method of total lipid extraction and purification. Can. J. Biochem. Physiol. 37, 911917.

Brochier-Armanet C., Boussau B., Gribaldo S. and Forterre P. (2008) Mesophilic crenarchaeota: proposal for a third archaeal phylum, the Thaumarchaeota. Nature Rev. Microbiol. 426, 245252.

Donders T. H., Weijers J. W. H., Musterman M., Kloosterboervan Hoeve M. L., Buckles L. K., Pancost R. D., Schouten S., Sinninghe Damsté J. S. and Brinkhuis H. (2009) Strong climate coupling of terrestrial and marine environments in the Miocene of northwest Europe. Earth Planet. Sci. Lett. 281, 215-225.

Engstrom D. R. and Wright, Jr., H. E. (1984) Chemical stratigraphy of lake sediments as a record of environmental change. In Lake Sediments and Environmental History (eds. E. Y. Haworth and J. W. G. Lund). Leicester University Press, Leicester, pp. 11-68.

Fawcett P. J., Werne J. P., Anderson R. S., Heikoop J. M., Berke M. A., Smith S. J., Goff F., Donohoo-Hurley L., CisnerosDozal L. M., Schouten S., Sinninghe Damsté J. S., Huang Y., Toney J., Fessenden J., WoldeGabriel G., Atudorei V., Geissman J. W. and Allen C. D. (2011) Extended megadroughts in the southwestern United States during Pleistocene interglacials. Nature 470, 518-521.

Harvey H. R., Fallon R. D. and Patton J. S. (1986) The effect of organic matter and oxygen on the degradation of bacterial membrane lipids in marine sediments. Geochim. Cosmochim. Acta 50, 795-804.

Huguet C., Hopmans E. C., Febo-Ayala W., Thompson D. H., Sinninghe Damsté J. S. and Schouten S. (2006) An improved method to determine the absolute abundance of glycerol dibiphytanyl glycerol tetraether lipids. Org. Geochem. 37, 1036-1041.

Huguet C., Martens-Habbena W., Urakawa H., Stahl D. A. and Ingalls A. E. (2010a) Comparison of extraction methods for quantitative analysis of core and intact polar glycerol dialkyl glycerol tetraethers (GDGTs) in environmental samples. Limnol. Oceanogr. Methods 8, 127-145.

Huguet A., Fosse C., Metzger P., Fritsch E. and Derenne S. (2010b) Occurrence and distribution of non-extractable glycerol dialkyl glycerol tetraethers in temperate and tropical podzol profiles. Org. Geochem. 41, 833-844.

Kaiser H. F. (1958) The varimax criterion for analytic rotation in factor analysis. Psychometrika 23, 187-200.
Kennicutt M. C. (1988) The effect of biodegradation on crude oil bulk and molecular composition. Oil Chem. Pollut. 4, 89-112.

Keough B. P., Schmidt T. M. and Hicks R. E. (2003) Archaeal nucleic acids in picoplankton from great lakes on three continents. Microb. Ecol. 46, 238-248.

Kim J.-H., Schouten S., Hopmans E. C., Donner B. and Sinninghe Damsté J. S. (2008) Global sediment core-top calibration of the TEX $_{86}$ paleothermometer in the ocean. Geochim. Cosmochim. Acta 72, 1154-1173.

Kim J.-H., van der Meer J., Schouten S., Helmke P., Wilmott V., Sangiorgi F., Koç N., Hopmans E. C. and Sinninghe Damsté J. S. (2010) New indices and calibrations derived from the distribution of crenarchaeal isoprenoid tetraether lipids: implications for past sea surface temperature reconstructions. Geochim. Cosmochim. Acta 74, 4639-4654.

Koga Y., Akagawa-Matsusita M., Ohga M. and Nishihara M. (1993) Taxonomic significance of the distribution of component parts of polar ether lipids in methanogens. Syst. Appl. Microbiol. 16, 342-351.

Lipp J. S., Morono Y., Inagaki F. and Hinrichs K.-U. (2008) Significant contribution of Archaea to extant biomass in marine subsurface sediments. Nature 454, 991-994.

Lipp J. S. and Hinrichs K.-U. (2009) Structural diversity and fate of intact polar lipids in marine sediments. Geochim. Cosmochim. Acta 73, 6816-6833.

Liu X., Leider A., Gillespie A., Gröger J., Versteegh G. J. M. and Hinrichs K.-U. (2010) Identification of polar lipid precursors of the ubiquitous branched GDGT orphan lipids in a peat bog in Northern Germany. Org. Geochem. 41, 653-660.

Liu X., Lipp J. S. and Hinrichs K.-U. (2011) Distribution of intact and core GDGTs in marine sediments. Org. Geochem. 42, 368375.

Llirós M., Gich F., Plasencia A., Auguet J.-C., Darchambeau F., Casamayor E. O., Descy J.-P. and Borrego C. (2010) Vertical distribution of ammonia-oxidizing crenarchaeota and methanogens in the epipelagic waters of Lake Kivu (RwandaDemocratic Republic of the Congo). Appl. Environ. Microbiol. 76, 6853-6863.

Logemann J., Graue J., Köster J., Engelen B., Rullkötter J. and Cypionka H. (2011) A laboratory experiment of intact polar lipid degradation in sandy sediments. Biogeosciences 8, 25472560.

Martens-Habbena W., Berube P. M., Urakawa H., de la Torre J. R. and Stahl D. A. (2009) Ammonia oxidation kinetics determine niche separation of nitrifying Archaea and Bacteria. Nature 461, 976-979.

Meyers P. A. and Teranes J. L. (2001) Sediment organic matter. In Tracking Environmental Change Using Lake Sediments (eds. W. M. Last and J. P. Smol). Kluwer Academic Publishers, Dordrecht, The Netherlands, pp. 239-269.

Nixon S. W. (1995) Metal Inputs to Narragansett Bay: A history and Assessment of Recent Conditions. Rhode Island Sea Grant, Narragansett, RI.

Oba M., Sakata S. and Tsunogai U. (2006) Polar and neutral isopranyl glycerol ether lipids as biomarkers of archaea in nearsurface sediments from the Nankai Trough. Org. Geochem. 37, 1643-1654.

Opperman B. I., Michaelis W., Blumenburg M., Frerichs J., Schulz H. M., Schippers A., Beaubien S. E. and Krüger M. (2010) Soil microbial community changes as a result of long-term exposure to a natural $\mathrm{CO}_{2}$ vent. Geochim. Cosmochim. Acta 74, $2697-$ 2716.

Pancost R. D., Coleman J. M., Love G. D., Chatzi A., Bouloubassi I. and Snape C. E. (2008) Kerogen-bound glycerol dialkyl tetraether lipids released by hydropyrolysis of marine sedi- 
ments: a bias against incorporation of sedimentary organisms? Org. Geochem. 39, 1359-1371.

Pearson E. J., Juggins S., Talbot H. M., Weckström J., Rosén P., Ryves D. B., Roberts S. J. and Schmidt R. (2011) A lacustrine GDGT-temperature calibration from the Scandinavian Arctic to Antarctic: renewed potential for the application of GDGTpaleothermometry in lakes. Geochim. Cosmochim. Acta $\mathbf{7 5}$, 6225-6238.

Peterse F., Nichol G. W., Schouten S. and Sinninghe Damsté J. S. (2010) Influence of soil $\mathrm{pH}$ on the abundance and distribution of core and intact polar lipid-derived branched GDGTs in soil. Org. Geochem. 41, 1171-1175.

Peterse F., Hopmans E. C., Schouten S., Mets A., Rijpstra W. I. C. and Sinninghe Damsté J. S. (2011) Identification and distribution of intact polar branched tetraether lipids in peat and soil. Org. Geochem. 42, 1007-1015.

Pitcher A., Hopmans E. C., Schouten S. and Sinninghe Damsté J. S. (2009) Separation of core and intact polar archaeal tetraether lipids using silica columns: insights into living and fossil biomass contributions. Org. Geochem. 40, 12-19.

Pitcher A., Hopmans E. C., Mosier A. C., Park S.-J., Rhee S.-K., Francis C. A., Schouten S. and Sinninghe Damsté J. S. (2011) Core and intact polar glycerol dibiphytanyl glycerol tetraether lipids of ammonia-oxidizing Archaea enriched from marine and estuarine sediments. Appl. Environ. Microbiol. 77, 3468-3477.

Pitcher A., Rychlik N., Hopmans E. C., Spieck E., Rijpstra W. I. C., Ossebar J., Schouten S., Wagner M. and Sinninghe Damsté J. S. (2010) Crenarchaeol dominates the membrane lipids of Candidatus Nitrososphaera gargensis, a thermophilic Group I.1b archaeon. ISME J. 4, 542-552.

Powers L. A., Johnson T. C., Werne J. P. and Castañeda I. S. (2005) Large temperature variability in the southern African tropics since the Last Glacial Maximum. Geophys. Res. Lett. 32, L08706. doi:10.1029/2004GL002014.

Powers L., Werne J. P., Vanderwoude A. J., Sinninghe Damsté J. S., Hopmans E. C. and Schouten S. (2010) Applicability and calibration of the $\mathrm{TEX}_{86}$ paleothermometer in lakes. Org. Geochem. 41, 404-413.

Rhode Island Department of Environmental Management (RIDEM), Office of Water Resources (2007) Total maximum daily loads for phosphorus to address 9 eutrophic ponds in Rhode Island, Providence, RI.

Schouten S., Forster A., Panoto F. E. and Sinninghe Damsté J. S. (2007a) Towards calibration of the $\mathrm{TEX}_{86}$ palaeothermometer for tropical sea surface temperatures in ancient greenhouse worlds. Org. Geochem. 38, 1537-1546.

Schouten S., Hopmans E. C., Schefuß E. and Sinninghe Damsté J. S. (2002) Distributional variations in marine crenarchaeotal membrane lipids: a new tool for reconstructing ancient sea water temperatures? Earth Planet. Sci. Lett. 204, 265-274.

Schouten S., Huguet C., Hopmans E. C., Kienhuis M. V. M. and Sinninghe Damsté J. S. (2007b) Analytical methodology for $\mathrm{TEX}_{86}$ paleothermometry by high-performance liquid chromatography/atmospheric pressure chemical ionization-mass spectrometry. Anal. Chem. 79, 2940-2944.

Schouten S., Hopmans E. C., Baas M., Boumann H., Standfest S., Könneke M., Stahl D. A. and Sinninghe Damsté J. S. (2008) Intact membrane lipids of "Candidatus Nitrosopumilus maritimus", cultivated representative of the cosmopolitan mesophilic Group I Crenarchaeota. Appl. Environ. Microbiol. 74, 24332440.

Schouten S., Middelburg J., Hopmans E. C. and Sinninghe Damsté J. S. (2010) Fossilization and degradation of intact polar lipids in deep subsurface sediments: a theoretical approach. Geochim. Cosmochim. Acta 74, 3806-3814.
Schubotz F., Wakeham S. G., Lipp J. S., Fredricks H. F. and Hinrichs K.-U. (2009) Detection of microbial biomass by intact polar membrane lipid analysis in the water column and surface sediments of the Black Sea. Environ. Microbiol. 11, 2720-2734.

Shah S. S., Mollenhauer G., Ohkouchi N., Eglinton T. I. and Pearson A. (2008) Origins of archaeal tetraether lipids in sediments: Insights from radiocarbon analysis. Geochim. Cosmochim. Acta 72, 4577-4594.

Sinninghe Damsté J. S., Schouten S., Hopmans E. C., van Duin A. C. T. and Geenevasen J. A. J. (2002) Crenarchaeol: the characteristic core glycerol dibiphytanyl glycerol tetraether membrane lipid of cosmopolitan pelagic crenarchaeota. $J$. Lipid Res. 43, 1641-1651.

Sinninghe Damsté J. S., Ossebaar J., Abbas B., Schouten S. and Verschuren D. (2009) Fluxes and distribution of tetraether lipids in an equatorial African lake: constraints on the application of the $\mathrm{TEX}_{86}$ paleothermometer and BIT index in lacustrine settings. Geochim. Cosmochim. Acta 73, 4232-4249.

Sinninghe Damsté J. S., Rijpstra I. C., Hopmans E. C., Weijers J. W., Foesel B. U., Overmann J. and Dedysh S. N. (2011) 13,16Dimethyl octacosanedioic acid (iso-diabolic acid): a common membrane-spanning lipid of Acidobacteria subdivisions 1 and 3. Appl. Environ. Microbiol. 77, 4147-4154.

Spang A., Hatzenpichler R., Brochier-Armanet C., Rattei T., Tischler P., Spieck E., Streit W., Stahl D. A., Wagner M. and Schleper C. (2010) Distinct gene set in two different lineages of ammonia-oxidizing archaea supports the phylum Thaumarchaeota. Trends Microbiol. 541, 331-340.

Sun Q., Chu G., Liu M., Xie M., Li S., Ling Y., Wang X., Shi L., Jia G. and Liu H. (2011) Distributions and temperature dependence of branched glycerol dialkyl glycerol tetraethers in recent lacustrine sediments from China and Nepal. $J$. Geophys. Res. 116, G01008. doi:10.1029/2010JG001365.

Sturt H. F., Summons R. E., Smith K., Elvert M. and Hinrichs K.U. (2004) Intact polar membrane lipids in prokaryotes and sediments deciphered by high-performance lipid chromatograpy/electrospray ionization multistage mass spectrometry - new biomarkers for biogeochemistry and microbial ecology. Rapid Commun. Mass Spectrum. 18, 617-628.

Tierney J. E. and Russell J. M. (2009) Distributions of branched GDGTs in a tropical lake system: implications for lacustrine application of the MBT/CBT paleoproxy. Org. Geochem. 40, 1032-1036.

Tierney J. E., Russell J. M., Huang Y., Sinninghe Damsté J. S., Hopmans E. C. and Cohen A. S. (2008) Northern hemisphere controls on tropical southeast African climate during the past 60,000 years. Science 322, 252-255.

Tierney J. E., Mayes M. T., Meyer N., Johnson C., Swarzenski P. W., Cohen A. S. and Russell J. M. (2010a) Late-twentiethcentury warming in Lake Tanganyika unprecedented since AD 500. Nat. Geosci. 3, 422-425.

Tierney J. E., Russell J. M., Eggermont H., Hopmans E. C., Verschuren D. and Sinninghe Damsté J. S. (2010b) Environmental controls on branched tetraether lipid distributions in tropical East African lake sediments. Geochim. Cosmochim. Acta 74, 4902-4918.

Tyler J. J., Nederbragt A. J., Jones V. J. and Thurow J. W. (2010) Assessing past temperature and soil $\mathrm{pH}$ estimates from bacterial tetraether membrane lipids: Evidence from the recent lake sediments of Lochnagar, Scotland. J. Geophys. Res. - Biogeosci. 115, G01015. doi:10.1029/2009JG001109.

Weijers J. W. H., Schouten S., Hopmans E. C., Geenevasen J. A. J., David O. R. P., Coleman J. M., Pancost R. D. and Sinninghe Damsté J. S. (2006) Membrane lipids of mesophilic anaerobic bacteria thriving in peats have typical archaeal traits. Environ. Microbiol. 8, 648-657. 
Weijers J. W. H., Schouten S., van den Donker J. C., Hopmans E. C. and Sinninghe Damsté J. S. (2007a) Environmental controls on bacterial tetraether membrane lipid distribution in soils. Geochim. Cosmochim. Acta. 71, 703-713.

Weijers J. W. H., Schefuß E., Schouten S. and Sinninghe Damsté J. S. (2007b) Coupled thermal and hydrological evolution of tropical Africa over the last deglaciation. Science 315, 17011704.

Weijers J. W. H., Panoto E., van Bleijswijk J., Schouten S., Rijpstra W. I. C., Balk M., Stams A. J. M. and Sinninghe Damsté J. S. (2009) Constraints on the biological source(s) of the orphan branched tetraether membrane lipids. Geomicrobiol. J. 26, 402414.

Weijers J. W. H., Wiesenberg G. L. B., Bol R., Hopmans E. C. and Pancost R. D. (2010) Carbon isotopic composition of branched tetraether membrane lipids in soils suggest a rapid turnover and a heterotrophic life style of their source organism(s). Biogeosci. Discuss. 7, 3691-3734.

White D. C., Davis W. M., Nickels J. S., King J. D. and Bobbie R. J. (1979) Determination of the sedimentary microbial biomass by extractable lipid phosphate. Oecologia 40, 51-62.

Wuchter C., Schouten S., Coolen M. J. L. and Sinninghe Damsté J. S. (2004) Temperature-dependent variation in the distribution of tetraether membrane lipids of marine Crenarchaeota: impli- cations for TEX86 paleothermometry. Paleoceanography 19, PA4028, doi:10.10269/2004PA001041.

Van Mooy B. A. S. and Fredricks H. F. (2010) Bacterial and eukaryotic intact polar lipids in the eastern subtropical South Pacific: water-column distribution, planktonic sources, and fatty acid composition. Geochim. Cosmochim. Acta 74, 64996516.

Van Mooy B. A. S., Rocap G., Fredricks H. F., Evans C. T. and Devol A. H. (2006) Sulfolipids dramatically increase phosphorus demand by picocyanobacteria in oligotrophic marine environments. Proc. Nat. Acad. Sci. U.S.A. 103, 8607-8612.

Zink K.-G. and Mangelsdorf K. (2004) Efficient and rapid method for extraction of intact phospholipids from sediments combined with molecular structure elucidation using LC-ESI-MS-MS analysis. Anal. Bioanal. Chem. 380, 798-812.

Zink K.-G., Vandergoes M. J., Mangelsdorf K., DieffenbacherKrall A. C. and Schwark L. (2010) Application of bacterial glycerol dialkyl glycerol tetraethers (GDGTs) to develop modern and past temperature estimates from New Zealand lakes. Org. Geochem. doi:10.1016/j.orggeochem.2010.03.004.

Associate editor: Josef Werne 